of the fisheries by every mesns in their power, and to impose no restrictions or regulations upon them which were not clearly consistent with that object. I have neither time nor inclination again to cleal with all the old arguments which year after year have been brouglat forward to show that our sea fisheries are being ruined. It is not quite two years since $\mathrm{I}$ entered at some length into the subject in my work on "Deep-sea Fishing and Fishing-boats," and the question is not one that can be discussed in a few lines, or even pages. But I may ask Prof. Newton how he reconciles his belief in a falling-off in the supply of sea fish with the recent considerable evlargement of Billingsgate Market, the continued immense fish traffic on the railways, and the large addilions which have been made, and are now being made, to the capital invested in fishing-boats and gear? Brixham alone has added twelve new large trawlers, costing nearly $1,200 l$. each, to her fleet in the present year; and the shipwrights there were hard at work on several more for other stations when I visited the place last month. Prof. Newton rightly calls science to the aid of the sea fisheries, for there is still an immense deal to be learnt about the economy of fishes which may help the fishermen in their work. He makes no reference, however, to the important discnveries which have already been made by Professors Sars and Malm on the coast of Norway. The investigations of the former naturalist especially, carried on for several years, have resulted in showing that there need be little fear of disturbing the "spawning beds" of most of our edilile sea fishes, as the spawn of almost all those in chief request is not deposited on the bottom, but floats during the whole process of development.

I will not enter into the question of destroying the balance of nature, on which Prof. Newton laid so much stress in his observations at Glasgow, because $I$ believe we are all too ignorant of the conditions affecting it to be able to do more than theorise on the subject; but I would ask my friend, assuming he is correct in his belief that cur sea fisheries are falling off, whether he has considered the probable effect on them and on the balance of nature, of the tens of thousands of additional gulls, guillemots, S.c., which I hope will result from our sea birc's being undisturbed during the breeding season, under the Sea Birds' Protection Act, of which he was such an earnest advocate?

I do not know on what evidence he grounds his belief in the decline of our sea fisheries ; but I have no hesitation in saying, as the result of my inquiries during the last few years, that the average annual produce of those fisheries has considerably increased since the Royal Commissioners were engaged in inquiring into their general conjition. Bad weather has had an important effect in some years in interrupting the fishermen's work ; but fluctuations from such causes have continually occurred, and they will undoubtedly happen again.

E. W. H. HOLDSWORTY

\section{Mr. Wallace and his Reviewers}

I Din not intend to take any public notice of reviews or criticisms of my book on "Geographical Distribution"; Mr. Gill's letter, however, calls for a few remarks. I have first to thank him for pointing out the errors of a previous critic, and also for a list of erratic in the account of North American freshwater fishes. He very truly remarks, that had $I$ heen acquainted with ichthyology and its literature these errors might have been avoided; but he has overlcoked the fact that I have twice stated (rol. i., p. Ior and vol. ii. p. I68) that the part of my work relating: to fishes is, practically, a summary of Dr. Giinther's Catalogue. The labour of going through such an extensive work for the purpose of extracting and tabulating summaries of the gengraphical materials it contains, was very sreat, and no doubt I have made some errors. Most of those indicated by Mr. Gill depend, however, either on differences of classification and nomenclature, or on additions to North American ichthyology since the date of Dr. Günther's work, and are therefore due to the plan of this part of my book, and not to oversight. Although possessing a tolerable acquaintance with the literature of ornithology, I had found the task of collating and combining the latest information into a uniform system of classification and nomenclature to be one which severely taxed whatever linowledge and literary ability I possessed. To have attempted to do the same thing in a class of animals which $I$ had never studied would, I felt sure, have resulted in great confusion, and have been far less satisfactory and reliable than the course I have adopted. Had I been able to find any work giving a general account of the fishes of temperate North America, I should gladly have availed myself of it, but I do not gather from Mr. Gill's letter that any such work exists; and notwithstanding the great imperfection of the results (in the eyes of a specialist) as regards the fishes of the United States, I still think I exercised a wise discretion in confining myself to the vast mass of materials, classified on a uniform system, which Dr. Günther's Catalogue afrords.

I may here add, that the " 24 peculiar genera" mentioned by me are in addition to the " 5 peculiar family types" - making together the " 29 peculiar genera" referred to in the succeeding paragraph - so that the contradiction alluded to by Mr. Gill is only apparent.

Dorking, October 30 Alfred R. Wallace:

\section{Self-fertilisation of Plants}

IN NATURE, vol. xiv. p. 475, I find an abstract of $\mathrm{Mr}$. Meehan's paper on the "self-fertilisation" of Browailia elata. When I frrst saw this paper in the Procecdinzs of the Philadelphia Academy of Natural Sciences, I suspected that the observation was incomplete and the inference hasty. It is therein stated that the densely bearded connectives of the upper anthers completely close the tube of the corolla with a bearded mass; that "no insect can thrust its proboscis into the tube except through this mass ; and in it has foreign pollen adherent to it, it will be cleaned off by the beard ; furthermore, the very act of penetration will thrust the anthers forward on to the pistil [meaning stigma], and aid in rupturing the pollen-sacs [opening the auther cells?], and securing self-fertilisation." My inspection of the flower showed that the orifice of the tube was clearly pervious on the (morphologically) anterior side by a chink, which is nearly divided by a crust of the tube into two orifices, one exactly before each anther-cell; a hog's bristle, slightly moistened, on being thrust down these passages in a freshly open flower, and then withdrawn, was found to have the inserted part well sup. plied with adherent pollen, so that it was not "cleaned off by the beard," nor was it cleaned off by introduction into the orifice of a second flower.

As to self-firtilisation being brought about by the thrusting of the overhanging anthers down upon the stigma, this seems to be effectually prevented by the lodgment of these anthers in a pair of cup-like concavities at the back of the stigma, so as to keep them quite away from the actual stigmatic surface. It is obvious that if insects ever self-fertilise Brocuallia it is by carrying down upon their tongue or proboscis some pollen from the upper anthers; but in this operation, passing from flower to flower, they are quite as likely to cross-fertilise them. The blossoms are freely visited by Hymenotitira and Lepidoplera of various sorts. It is quite probable that the other cases of "self-fertilisation "brought forward by Mr. Meehan may equally bear a different interpretation from his own. ASA GRAY

Cambridge, Mass., U.S.A.

\section{Nitrite of Amyl}

Mr. George Aryarch, of Cincinnati, asks of me through the columns of NATURE two questions concerning the nitrite of amyl, which I may briefly answer as follows:-(I) Nitrite of amyl has been used, and with considerable success, in the treatment of epilepsy, but its application can only be entrusted to a regular practitioner of medicine who understands its mode of action. (2) It has not as yet been proved to be of service in the treatment of paralysis.

B. IV. Richaroson

\section{CAPT. NARES'S REPORT}

\section{I.M.S. Alert, at Valentia,} October 27,1876 .

SIR,-I have the honour to report in detail the proceedings of the Expedition since leaving Upernivik on July 22,1875 , as follows :--

The Alert and Discovery, one ship in tow of the other, left Upernivik, from which port I last had the honour of addressing you, on July $22,1875$.

A dense fog prevailing at sea I steamed to the northward, between the islands and the main land, experiencing clear and calm weather until arriving near Kangitok

I Communicatec by the Lords Commissioners of the Admiralty. 
Island, when the fog, stealing in from the sea, gradually obtained the mastery, and completely enveloped us. The numerous picturesque rocky islands and reefs in this sheltered labyrinthine passage are so incorrectly represented in the public charts that a pilot is at present a necessity. The one who accompanied us, an Esquimaux, informed me that many of the likely-looking channels are bridged across with sunken reefs, and from the many rocks we saw lying just awash directly in our passage, I have reason to believe his statement.

The large discharging Upernivik Glacier having only one outlet leading direct to the sea, its numerous icebergs of all sizes are collected in great numbers by the eddy tides and currents among the islets situated to the southward, and tend to keep the channels completely closed until late in the season; but when once open in July by some of the bergs grounding on rocks, and others, by their height above the flotation line, affording certain evidence of deep water, they assist rather than impede navigation during calm weather. On the morning of the

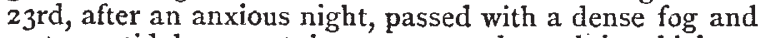
a strong tidal current in a narrow channel, in which we could obtain no bottom with 100 fathoms of line at a cable's length of the shore, and with the Discovery in tow, during a momentary clearance of the atmosphere, two Esquimaux in their kyacks were observed close to us. After consulting with them through Christian Petersen, Danish and Esquimaux interpreter, they volunteered to conduct us to an anchorage. On following them to the position they denoted, and obtaining no bottom with the hand-lead line at the main chains, I felt the bow of the ship glide slowly up on the ground. Through the fog we could then see that the land was within fifty yards of us. The Esquimaux had evidently not considered that our ships required a greater depth of water to float in than their own frail canoes. As it was nearly low water, and the tide still falling, I allowed the ship to remain quiet where she was, the Discovery still hanging to us by her towing hawser, and took advantage of the enforced delay by landing the ships' companies to wash their clothes.

The fog lifted slightly as the day advanced, and as the tide rose the ship floated without having incurred any strain or damage whatever. I then proceeded to sea, discharging the pilot, who was not to blame for our mishap, off the north shore of Kangitok, the outlying island of the group, after passing which the channel presents no diffculties.

Thinking that probably a distorted account of our getting on shore might reach Europe, at the last moment I wrote a hasty pencil letter to Capt. Evans, hydrographer, merely to point out how very unimportant the slight detention had been.

By 4 P.M. we had passed the Brown Islands with a sea perfectly clear of ice before and around us. Having given much study and consideration to the question, and a high and very steady barometer following a south-east wind, denoting that the calm settled weather we had lately enjoyed was likely to continue, I decided to force my way through the middle ice of Baffin's Bay instead of proceeding by the ordinary route round Melville Bay. Accordingly both ships proceeded at full speed to the westward, racing in company for Cape York, with only about a dozen icebergs in sight ahead, floating quietly on a calmly mirrored sea to dispute our passage. As we passed out from the land the fog gradually dissolved and revealed a magnificent and unique panorama of the icecapped mountains of Greenland which give birth to the Upernivik Glacier, fronted by innumerable icebergs, and, at a long distance in advance, by the group of scattered black islets among which we had passed the previous night, and of which Kangitok is the northernmost.

At 1.30 A.M. of the 24th we ran into the pack at a distance of seventy miles from Kangitok. It consisted of open-sailing ice rom one to three feet, and occasionally four feet in thickness. The floes were at first not larger than 250 yards in diameter, and very rotten, dividing readily, and opening a channel when accidentally struck by the ship. The reflection in the sky near the horizon denoted that while the ice was very open to the southward of us, it was apparently closer packed to the northward. About 6 A.M., when we had run thirty miles through the ice, it gradually became closer, and the floes larger, estimated as measuring one mile in diameter, and necessitated a discriminating choice to be made of the best channels. For fourteen hours, during which time we ran sixty miles, the ice continued in much the same state, never close enough to suggest the probability of a barrier occurring, and yet keeping the look-out in the "Crow"s Nest" fully employed. After 8 P.M. the channels of water became decidedly broader and more numerous, so I gradually altered course to the northward, steering directly for Cape York, the ice becoming more and more open as we advanced.

At 9.30 A.M. of July 25 we sighted the high land north of Cape York, and at II o'clock, much to the astonishment of the ice quartermasters, who continually declared, "It will ne'er be credited in Peterhead," we were fairly in the " north water," and able again to think about economising coal, having come through the middle ice in thirtyfour hours without a check; but it is my duty to add, with not a few scratches along the water-line.

In consequence of our having made a successful voyage through the middle it should not be too hastily concluded that a similar passage can always be commanded. The middle pack is justly dreaded by the most experienced ice navigators. Large icebergs and surface-ice, floating in water at various depths, when affected either by wind or an ocean current, move at different rates; hence, when in motion, as one passes the other, the lighter surface-ice, incapable of controlling its course, is readily torn in pieces by the heavy massive iceberg; therefore, a ship once entrapped in pack ice among icebergs, unless she has water space to allow her to move out of the way, is constantly in danger of being carried forcibly against a berg. On such occasions man is powerless, for he can take no possible means to save his vessel. Before steam-vessels were used for ice navigation the masters of sailing ships, being unable to take full advantage of a favourable calm, very wisely seldom ventured to force their way through ths middle ice, and chose, in preference, the chance of delay in making the safer passage through Melville Bay, where, by securing their vessel in dock in the fixed land ice, they ran less danger of being nipped whilst forcibly detained by the channels through the ice remaining closed.

At the latter end of July with an open season, indicated by the main pack not being met with nearer than fifty miles from the land, in about latitude $73^{\circ} 20^{\prime}$ and a continuous calm, to allow the northerly running current on the Greenland shore and the southerly running one on the western side of Baffin's Bay to open up the ice, I believe a passage can always be made by a steam-vessel ; but, unless this favourable combination of circumstances is met with, so far as the scanty knowledge we at present possess enables us to judge, the passage must still be said to be doubtful.

Soon after sighting land and getting clear of the drift ice, the Discovery parted company to communicate with the natives at Cape York, while the Alert proceeded towards the Carey Islands. A vast collection of icebergs, many of them aground, were thickly crowded together off the Cape, and in lines parallel with the coast trending towards Conical Rock and Cape Atholl. In the offing they were less numerous, which I attribute to the southerly current which we experienced the following day on our passage to the Carey Islands, catching up and carrying with it to the southward those that drift out from the main body to the westward beyond the influence of the north. running current on the Greenland coast. 
During the stay of the Discovery at Cape York the natives were communicated. with through Christian Petersen, interpreter, and Hans the Esquimaux, but as the brother of the latter was absent on a hunting excursion for an uncertain priod, Capt. Stephenson wisely gave up the hope of obtaining his services for the benefit of the expedition, and pushed on for the Carey Islands, where he joined company with the Alert; the two ships arriving there at midnight on July 26.

A depôt of 3,600 rations and a boat were landed on the south-east point of the sourh-east island, and a record deposited in a conspicuous cairn on the summit. The "Expedition" then proceeded, steaming with as much economy of coal as possible, northward through a calm sea, with bright clear weather. With the exception of the many scattered icebergs there was no ice in sight from the summit of Carey Islands. Passing between Hakluyt and Northumberland Islands, the ships were abeam of Cape Robertson, by 8 P.M. of July 27 . Ice apparently fast to the shore, completely closed Inglefield Gulf, east of Cape Acland, but both entrances to the gulf were clear. At 8 A.M of July 28 , five days and a half from leaving the anchorage of Upernivik, I had the satisfaction of seeing the "Expedition" at anchor near Port Foulke, with the entrance of Smith's Sound perfectly clear of ice, and none coming to the southward with a fresh northerly wind.

While Capt. Stephenson explored the head of Foulke Fiord to ascertain its suitability as a station for winter quarters for any relief vessel coming to our assistance, Commander Markham and myself proceeded in a boat to Littleton Island and Life Boat Cove, the scene of the wreck of the Polaris. The cache mentioned by Dr. Emil Bessels and Mr. Bryant of the "United States North Pole Expedition" as the depository of certain instruments and boxes of books was very readily discovered, but contained nothing. Articles of clothing and numerous small caches containing seal and walrus meat were scattered about all over the small peninsulas in the neighbourhood of the late winter quarters, and near the ruins of the house, but apart from each other and without any protection, were found four or five boxes, each covered with heavy stenes to prevent the winds moving them, and having the lids secured on by a rope. Besides one thermometer, unfortunately not a self-registering one, they contained scraps of skin clothing, old mitts, carpenter's tools, files, needles, and many small articles of the greatest use to the Esquimaux, but apparently they had not been disturbed since the abandonment of the staion. A few books were found in the different boxes, and a copy of the log, or the actual log itself, from the departure of the vessel from the United States up to May 20 the following year. No pendulum, transit instrument, or chronometer was found. Three skin boats left on the shore, weighted down with stones, were in fair order. The smallest one was taken for conveyance to Cape Sabine.

On returning to the Alert we landed at Littleton Island, and on the south-west brow erected a cairn, and deposited a notice containing a short account of the movements and prospects of the expedition up to that time. There was no ice in sight from a high station on Littleton Island; but the sporismen roaming over the higher grounds on the mainland reported on their return that they had distinguished an "ice-blink" to the northward.

Port Foulke is at present the best known station for winter quarters in the Arctic regions. A warm ocean current, combined with the prevailing northerly winds, acting at the narrow entrance of Smitn's Sound, keeps the ice constantly breaking away during the winter, causes an early spring and a prolific seal and walrus fishery. The moisture and warmth imparted to the atmosphere by the uncovered water moderates the seasons to such an extent that the land is more richly vegetated, and therefore attracts to the neighbourhood and supports Arctic life in greater abundance than other less favoured locali- ties. In addition to this great advantage-of obtaining an ample supply of fresh meat-connected as its waters are with the "north water" off Cape York, it can readily be communicated with every summer without more than the usual risks attending Arctic navigation.

On the mornirg of the 29th the two ships sailed across the strait for Cape Isabella, with fine weather; but as we approached the western shore a snow storm worked its way over the land from the interior, and reached us just as we arrived at the Cape. As the weather was so thick that no one on board the ships, except those employed in establishing the cairn and small depôt of provisions, could see its position, and there being therefore no reason for delaying the Discovery, Capt. Stephenson proceeded. The cairn was built on the summit of the outer easternmost spur of the Cape, at an elevation of about 700 feet from the water. On the boat returning on board at 5 P.M., I steamed to the northward for Cape Sabine, the wind having died away, but the weather continuing misty with snow. By 8 P.M., when we were fifteen miles north of Cape Isabella, ice was sighted between us and the shore, and necessitated our keeping well out from the land.

Early in the morning of July 30 , having run our distance for Cape Sabine I stopped steaming, and at 5 A.M., the mist clearing off, I observed the Discovery near the land apparently beset with a close pack five or six miles broad; no ice in sight to seaward. As I did not wish the two ships to separate, and the calm weather being favourable, I bored tnrough the pack, which, although apparently clise, opened sufficiencly to admit of the slow progress of the ship until we gained the land in company with the $D i s$ covery, and secured the ships in a convenient harbour, named after Lieut. Payer, the successful and energetic Arctic traveller, two miles to the southward of Cape Sabine. A depôt of 240 rations was established on the southernmost of the islets in a convenient position for travelling parties, a cairn being built on the summit of the highest and outer one, and a notice of our movements deposited there.

The pack in the offing consisted of floes from 5 to 6 feet thick, with occasionaliy much older and heavier floes Io to i2 feet thick intermixed with it, but all was very much decayed and honeycombed; still it could not be treated with the same impunity as the ice in the middle passage through Baffin's Bay.

I may here draw actention to the deceptive im sressions inexperienced people naturally receive when from a lofty look-out station they observe a sea unbordered by ice. The distance from Littleton Island to Cape Sabine is only twenty-five miles. On a clear evening, from an altitude of 700 feet, with the land and horizon distinctly vistble, no ice was in sight from the first-named place, and the prospects of the expedition as to attaining a higher latitude without trouble appeared to be precisely the same as when I looked over a boundless sea from the summit of one of the Carey Islands roo miles to the south ward, and yet the ships were twenty-four hours afterwards locked up by ice in a harbour near Cape Sabine. From Littleton Island the inexperienced observer would conclude that there was an open Polar Sea; from our present position he would as certainly conclude that his farther progress was for ever stayed, and that the sooner he looked for winter quarters the better.

The ships were detained at Payer Harbour for three days watching for an opening in the ice, getting under weigh whenever there appeared the slightest chance of proceeding onwards, but on each occasion being unable to pass Cape Sabine, were forced to return. Their restingplace proved to be an excellent station, well protected against the entrance of heavy floes, possessing a lofty look-out, and deep navigable channels to the north and south through which to proceed to sea immediately the ice opened with a favourable westerly wind. Being ad- 
vantageously situated near a prominent Cape, where the tidal currents run with increased velocity, it is however subject to squally winds; but in icy seas during the summer, when awaiting the opening of the ice, they are rather an advantage than otherwise, striving as they do with the sea currents, which is to be the chief worker in removing the impediments to a vessel's advance.

Early in the morning of August 4, after several hours of light south-westerly winds, the main pack, while remaining perfectly close and impenetrable to the northward, moved off from the land to a sufficient distance to enable the ships to pass to the westward round Cape Sabine. In the hope of finding a passage on the western side of the island, of which Capes Victoria and Albert are the prominent eastern points, sail was immediately made, and we succeeded, with only one short detention, in advancing twenty miles along the southern shores of Hayes Sound, and securing the ships in a snug harbour. In the neighbourhood the sportsmen discovered a richly vegetated valley with numerous traces of musk-oxen and other game. Two glaciers coming from nearly opposite directions, which, instead of uniting in their downward direction, abut the one against the other, and maintain a constant warfare for the mastery, a never-ending grapple for victory, suggested the name of Twin Glacier Valley for the locality.

The ice in the sound was one season old, and decaying so swiftly that if not drifted away it would in a week's time present no impediment to the advance of a steam vessel. On August 5 the strong tides and a south-westerly wind opened a channel to the north-west, and we gained a few miles in advance; but not wishing to expend much coal, were finally stopped in the light pack. After remaining sufficiently long to determine that the flood tide still came from the eastward, although the ebb or east running tide was apparently the stronger of the two, I pushed the ship through the pack towards the shore, and with Capt. Stephenson ascended a hill 1,500 feet high. From this station, the appearance of the land giving no prospect of a channel to the northward, and, moreover, the westerly wind having set in in strength, which we expected would open a passage to the eastward of Cape Albert, we decided to bear up and return to the entrance of the Sound; accordingly the ships made a quick run under sail to Cape Albert, arriving off which the wind died away leaving the ice loosely packed. A clear space of water being visible along the shore of the mainland to the northward, and the coast between Cape Victoria and Cape Albert affording no protection, I ran the two ships into the pack under steam, with the hope of forcing our way through, but before midnight they were hopelessly beset; and the floe, to which the ships were secured at a distance of Ioo yards apart, drifting rapidly towards an iceberg. Both ships were at once prepared for a severe nip, the rudders and screws being unshipped. At first the Discovery was apparently in the most dangerous position, but the floe in which we were sealed up by wheeling round, while it relieved Capt. Stephenson from any immediate apprehension, brought the Alert directly in the path of the advancing mass, which was steadily tearing its way through the intermediate surface ice. When only roo yards distant the iceberg, by turning slightly, presented a broader front to the approaching ice, which then accumulated in advance of it to such an extent as to fill up the angle, and form, as it were, a point or bow of pressed-up ice, sufficiently strong to itself divide and split up the floe, and act as a buffer in advance of the berg; and this it did in our case most successfully, our floe breaking up into numerous pieces. The ship herself escaped with a very light nip, and, sliding past the side without accident, was finally secured in the water space left in the wake of the iceberg by the faster drift of the surface ice.

The next twenty-four hours were spent in a constant struggle towards the shore through the pack, which fortunately consisted of ice seldom more than 4 feet in thickness, with occasional pieces up to 12 feet thick, formed by the over-riding and piling up of ordinary floes, and then cemented together by a winter's frost ; the worn down round-topped ice hummocks on these were from 6 to 8 feet above the water-line. The icebergs, evidently derived from inferior glaciers, were from 20 to 40 feet in height above water, and 100 yards in diameter.

Owing to the unsteady wind and the variable tidal currents we were unable to remain for long in any one pool of water-either the iceberg turned round and carried us with it to the exposed side, before we could change the position of the hawsers by which we were secured; or the pack ice, which was readily acted upon by the wind, drifting back the opposite way with any change, closed up the water space. Securing the ships in a dock in rotten ice in the presence of so many icebergs, was not advisable, and also would have carried the ships deeper into the pack to the southward. There was, therefore, no alternative before me but to get up full steam and dodge about as best we could, taking instant advantage of every change in our favour. The ships were seldom separated for long, and now as on all other occasions, they mutually assisted each other. The Discovery was handled by Capt. Stephenson and her officers in the most masterly and daring manner, combined with great judgment, qualities essential in arctic navigation. She, as well as the Alert, ran not a few hairbreadth escapes. Once in particular when in following us through a closing channel between an iceberg and heavy floe-piece, before getting quite past the danger she was caught and nipped against the berg, and had it not been for a fortunate tongue of projecting ice would certainly have had all her boats on the exposed side ground away from her. Fortunately, the moving ice pushed her clear, much in the same manner as it had done the Alert the previous day.

Having less beam than the Alert, and a finer bow, with the very great advantage of an overhanging stem, the Discovery is better adapted for forcing her way through a pack. It will be difficult ever to efface from my mind the determined manner in which, when the bluff-bowed leading ship had become imbedded in the ice, which by her impetus against it had accumulated round and sunk under her bows, and a great quantity by floating to the surface again in her wake, had helplessly inclosed her abaft, the Discovery was handled, when advancing to our rescue; having backed some distance astern, for the double purpose of allowing the débris ice from a former blow to float away and for the vessel to attain distance sufficient for the accumulation of momentum with which to strike a second, coming ahead at her utmost speed she would force her way into the ice burying her bows in it as far aft as the foremast, the commanding officer on the bowsprit, carefully conning the ship to an inch, for had the ice not been struck fairly it would have caused her to cannon off it against ourselves with much havoc to the two. From the moment of the first impact the overhanging stem necessarily caused the ship's bow to rise 3 or 4 feet as she advanced from 12 to 20 feet into the solid floe and imbedded herself before the force of the blow was expended, and as the ship's way was stopped, the overhanging weight, by settling down, crushed the ice down still further ahead. Frequently on these occasions her jib-boom was within touching distance of the Alert's boats! But after a little experience had been gained, such confidence had we in each other that there was not the slightest swerving in any one. Floes up to 4 feet in thickness, and in a soft state, that is melting, not freezing, may be charged with advantage, thicker or harder ice had better be left alone. It speaks well for our chronometers, and the manner in which they are secured, that their rates were little effected by the frequent concussions on this and on many after occasions. 
By 8 A.M. on the morming of the 8 th we had succeeded in reaching the land water off Cape Victoria, having sustained no more serious damage during this severe trial than sprung rudder heads, consequent on the frequent necessity of going full speed astern; all heartily glad to be out of the pack ice. The two islands marked on the chart, on the authority of Dr. Hayes, as existing in the entrance of Hayes Sound are, as originally represented by the present Admiral Inglefield, in reality joined; the three capes named by the latter, north of Cape Sabine, are very prominent headlands, and readily sighted from a ship's deck from any position north of Littleton Island. There is no sign of an inlet along the very slightly indented coast line between his Cape Camperdown and Cape Albert. His. Princess Marie Bay is the inlet north of the land in the middle of the sound, but whether that be an island or a peninsula remains to be determined; and his Cape Victoria is evidently one of the headlands on the present Grinnell Land.

It is necessarily an unthankful office to find fault with our predecessors; but navigators cannot be too careful how they remove from the chart names given by the original discoverers, merely because during a gale of wind a bearing or an estimated distance is a trifle wrong; and when the corrector or improver is also himself considerably wrong, and in fact produces a more unreliable chart than the first one, he deserves blame. The names given to the headlands undoubtedly discovered by Admiral Inglefield should not have been altered by Doctors Kane and Hayes, each of whom published very misleading delineations of the same coast.

It is as yet uncertain whether Hayes Sound is a channel or not. The flood tide coming from the eastward, the apparent continuity of the western hills, and the absence of berg pieces or heavy ice high up the sound, would lead to the supposition that it was closed; but considering the general configuration of the neighbouring land and the fact that the ebb or east running tidal current was stronger than that during the flood-but this the westerly wind might have occasioned-and the numerous Esquimaux remains which are usually found in channels, there seems no rcason why we may not reasonably expect the existence of a narrow opening leading to a western sea. The very decayed state of the ice would be the natural result cither from strong tidal currents in a long fiord or the increased strength of the ebb tide occasioned by an easterly set from the Polar Sea.

On passing what is called on the chart Cape Victoria, Commander Markham landed to ascertain the state of the ice, but a very thick fog and snowstorm coming on he was obliged to return. The ships were secured to the floe in Princess Marie opening which consisted of the last season's ice which had not cleared out : it was very much decayed but sufficiently strong to prevent our forcing our way through it-and in fact when pressing in with the flood time it became so compact that at one time the ship was in danger of being driven on shore. At high water it opened and we succeeded in crossing the bay and securing the ships to the land ice in Franklin Pierce Bay on the southern shore of Grinnell Land.

On the morning of August 9 , after depositing a record in a small cairn erected on a spur of the limestone hills, 200 feet above the sea, on the west side of the bay, one and a half miles east from Cape Harrison, we gained three miles of easting; but, being unable to round Cape Prescott, were compelled to make the ships fast to an extensive floe extending from that cape to Norman Lockyer Island, which stopped all further progress. Franklin Pierce Bay, which is about three miles broad and two and a haif $\mathrm{d} \in \mathrm{ep}$, and in which we found an unbroken smooth floe of one season's ice, is protected from any heavy pressure by Norman Lockyer Island and the Walrus Shoal, situated one mile further to the eastward; it is therefore a fit position for winter quarters. But, as far as we could judge during our short stay, there is very little game procurable in the neighbourhood. The shoal was so named in consequence of the numerous ancient remains of Esquimaux found on the island, who, by the number of bones found lying about, had evidently subsisted principally on these animals. At present this neighbourhood may be considered as the northern limit of their migration, only a very few having been seen farther to the north. The comparatively slugyish tidal motion at the entrance denotes that the coast lies out of the main run of the stream, and if so, Princess Marie opening will probably prove to be merely a deep inlet. In the extended basin of Smith's Sound the southerly current and the tidal streams run in a direct line between Cape Frazer and Cape Isabella, producing eddies and accumulating the ice in any open water space on either side of that course.

August being proverbially a calm month in the Arctic seas, and the western mountains protecting the coast from winds blowing off the shore, the ice is inclined to hug the land, and, except during strong westerly winds, a large amount of patience must be exercised by any one striving to advance to the northward. The pack in the offing in the main channel consisted principally of old floes which did not clear out of the sound during the previous season, mixed with light one-season ice, formed in Kennedy Channel and its numerous bays, and in Hall's Basin. Amongst these were scattered numerous icebergs discharged from the Humboldt Glacier, and the few smaller ones on the eastern shores, and here and there a heavy blue-topped hummocky floe of ancient ice from the Arctic basin, but of unknown thickness. By the scarcity of these the main drift of the northern ice is apparently in some other direction.

During the fortnight we were delayed in this neighbourhood, in the middle of August and the height of the Arctic summer, a constant watch was kept on the pack, and as oft $n$ as possible from high elevations, from which we were able to distinguish even the eastern shore, with its glacier and heavy barrier of fringing icebergs. Although small openings were seen occasionally, I am satisfied that north of Cape Sabine it was at no time navigable to the smallest extent, and that any vessel which endeavoured to force a passage through the middle ice here, where it is drifting steadily towards an evernarrowing opening, as many have succeeded in doing in the more open sea of Baffin's Bay, would decidedly be beset in the pack and be carried with it to the southward.

We were delayed near Walrus Shoal for three days, unable to move rnore than a mile in any direction, until August 12, when, during a calm, the ice set off shore with the ebb tide, and allowed us without much trouble to steam past Cape Hawks, and between it and Washington Irving (or Sphinx) Island-a very conspicuous landmark-but here the ice prevented any further movement, the flood tide closing in the channel by which we had advanced. A large depôt of 3,600 rations of provisions was landed on the northern side of Cape Schott, and a notice of our progress deposited in a cairn on the summit of Washington Irving Island. Two cairns were found there, but they contained no documents, and were much too old to have been built by Dr. Hayes in 1866 , the only time any traveller has journeyed past the position.

On the western shore of Dobbin Bay there is no shelter obtainable, and the tides run with much greater rapidity than off the coast farther to the westward. During the next ebb tide, August I3, after blasting a passage through a neck of ice, I succeeded in conducting the ships to the eastern shore, and docking them in an extensive floe four miles north-west of Cape Hilgard. A mile north of our position was an island, having a channel half a mile broad between it and the eastern shore of the bay, named Prince Imperial Island. The land ice which had not broken out this season extended from the island in a 
westerly direction across the bay. Several small icebergs were frozen in at the head of the bay, where there are some large discharging glaciers named after the Empress Eugenie. The land, as far as our explorations went, was very bare of game, and not well vegetated. A floe of last season's ice was observed in the bay, between Cape Hilgard and Cape Louis Napoleon, but off each of those headlands the piled-up ice foot denoted very heavy recent pressure from the eastward.

On the evening of August i 5 , after considerable labour, we succeeded in blasting and clearing away a barrier which separated the ships from a water channel leading beyond Cape Louis Napoleon, but so narrow was the channel that, notwithstanding the extreme care of Capt. Stephonson, the Discowery took the ground for a few minutes whilst steaming between the ice and the shallow slyore. By 8 A.M. of the 16 th we had advanced to within five miles of Cape Frazer, but here we again met with a block. Calm weather and spring tides caused much and constant movement in the ice, the main tendency being to drift to the southward at the rate of about five miles a day.

'The character of the pack had changed considerably, few iccbergs were seen that were not aground, and the floes consisted principally of old hummocky pieces pressed together, of from 12 to 20 feet in thickness, the surface beine studded over with worn-down hummocks of a blue bottle-glass colour, which denotes great age. In such ice it was impossible to cut into dock on account of the time it would occupy, even had we been provided with saws of sufficient length. Our only possible safety lay in keeping close in shore of grounded icebergs, but in doing so the two ships were obliged to separate. The Alert securing to one, and the Discuvery forcing herself in between three smaller ones farther in shore.

On the two following days, during which the ice continued to drift to the southward and westward, the constant movement of the heavy floes, nipping together with great force, like the closing of a gigantic pair of scissors, between which, if once caught, the ships would have been instantaneously crushed, caused much anxiety, and necessitated constant watchfulness and much labour on the part of the officers and crew; and all were much distressed at losing three or four miles of the ground previously gained. The rudders and screws were constantiy being shipped and unshipped, the midship boats were obliged to be turned inboard, on account of the ice touching their keels, and steam, when not in use, was always kept ready at twenty minutes' notice. Beyond wrenching the rudder-head, no serious damage occurred. On the 19:h, the highest spring tide, the ice near us became more open; and from a high station on Mount Joy I saw that we could at least regain our lost station, and might get further north. Knowing that this was our last chance during the present tides, and until the strong westerly winds set in, and the pack having opened for the first time, I risked boring my way into the pack for two miles, and by doing so entered a channel round Cape Frazer which had long been consider d as one of the most difficult milestones to pass on our passage north. By 9 P.A., after a few hours' delay during the flood tide which brought the ice inshore again, we were fairly in Kennedy Channel, secured to a floe off Cape John Barrow; only two days later in the year than when the Resolute was blown out of winter-quarters at Melville Island, in 1053 , and with a fortnight of the navigable season still bcfore us. Between Scoresby Bay and Dobbin Bay there is no protection obtainable except inside grounded icebergs; none of the shallow bays are deep enough to sheiter a ship from the pressure of heavy ice.

Soon after milnight the ice moved off shore, opening a passage, and again allowed us to proceed, the water spaces becoming more frequent and larger as we advanced northward. Passing the mouth of a large bay about ten miles deep, after making a very tortuous course through the ice and many narrow escapes of being driven to the southward again in the pack, we reached what we supposed to be Cape Collinson, the second of two capes to the north of the large bay, which must be intended to be represented on the chart as Scoresby Bay. But as Cape Frazer is placed eight miles and Scoresby Bay twenty miles too far north, and the rest of the western land very incorrectly delineated on the charts, it is difficult to say where we arrived, and yet for the present it is necessary for me to describe the advance of the expedition by reference to the published charts. I shall therefore continue to do so with an occasional necessary reference to our correct latitude.

Between Cape Collinson and Cape McClintock, the north point of Scoresby Bay, is a slight indentation in the coast from half to three-quarters of a mile in depth, but affording no protection. North of Cape Collinson the land trends slightly to the westward, and about three miles north of the Cape turns sharp to the west, forming Richardson Bay, which is much deeper than represented, probably four miles broad and six deep. A heavy iceberg firmly aground two miles from the land in the shallow bay north of Cape Collinson, which had evidently never moved this season, prevented a compact floe from floating off shore. The same iceberg caught all the ice that streamed down the west coast and round Richardson Bay, guiding it out towards the south-east, away from Cape Collinson, off which, and between it and the iceberg, was navigable water. In this pool the two ships were secured, watching for an opportunity to get north, and during the forced delay employing our energies in trying, by blasting, to unlock the land ice from the berg, and let it drift south, with the hope of releasing the ice to the northward; but perhaps it is fortunate we did not succeed, as by doing so, if the ice in the offing had not opened at the same time, our principal protection might have been lost, the iceberg itself being too small to form a pool under its lee sufficiently large for both ships, even had it been for one. A depôt of provisions was landed at Cape Collinson for our future travellers bound to the southward along the coast. The current was observed to run with greater rapidity to the southward than in the broader part of Smith's Sound. During each flood-tide about five miles of ice drifted past us ; for four hours of the ebb it remained stationary; thus aboat ten miles of ice drifted south daily, adding to the accumulation in the basin of Smith's Sound, unless, as is probable, it is carried as quickly into Baffin's Bay through the southern entrance. On the north side of each point on this shore the ice had piled up a wall-like barrier from 20 to 30 feet high, but elsewhere there was not much display of pressure.

On the morning of August $2 x$, the water channels in the middle of the straits looking very inviting, we made a start at the top of high water, but were led by the ice so much out from the land that I returned to our friendly protecting floe and iceberg until the next tide, first $\in n-$ deavouring to clear the nip of one against the other by ramming; but finding that it would cost too much in coal and shake of the ship to clear it completely, and too much powder to blast it away, I gave up the attempt, after consultation with Capt. Stephenson, and considering that the constant open channels in the offing denoted more water farther off. The two ships started again at 9 P.M., just before low water, and after a troublesome passage through about three miles of close heavy floe pieces, we passed into open leads of water, extending to the north-east up the straits. A bitter northerly wind, accompanied with mist and snow, freshening at the same time, carried the ice with great rapidity to the southward, and obliged us to beat to windward under steam and fore and aft sails, tacking frequently to avoid the heaviest streams of ice. After this snowstorm the land remained covered with snow for the season. 
By noon of the 22nd, after buffeting against a strong breeze, we succeeded in weathering the northern headland of the largest bay on the west coast, named on the latest charts Carl Ritter Bay, but agreeing by latitude and relative position with the neighbouring land on the north part of Richardson Bay. In this part of the channel there was very little ice, but three or four miles further north a heavy pack extended across towards Crozier Island, and obliged us to proceed in that direction. In the evening, the wind lulling, I took in the fore and aft sails, and steered through the most open channels to the northward, passing to the westward of Franklin Island, and at midnight we were abeam of Hans Island, with perfectly clear water between us and the eastern land; but streams of ice prevented our approaching the western shore. No deep inlet answering to the Carl Ritter Bay of the charts exists in its given latitude. Steaming to the northward, I endeavoured to close the western shore south of Cape Cracroft, but the ice prevented our doing so, and forced me to bear up to the eastward for Cape Bryant, passing which $I$ found the pack extending across from Cape Morton and Joe Island to Cape Lieber, with a south-westerly wind constantly adding to it by driving more ice to the northward through Kennedy Channel. The Discovery then landed a depôt of 240 rations at Cape Morton for use of any travelling party exploring Petermann Fiord, and the ships beat back to Bessels Bay, in the entrance of which we obtained a sheltered anchorage to the north of Hannah Island.

On the 24 th, the south-west wind still continuing, which I knew would open the ice on the western shore of Hall's Basin, I ascended Cape Morton. At an altitude of 2,000 feet it was perfectly calm, with a clear sky. The prominent capes of the channel were clearly visible-Cape Union seventy miles distant, and Cape Sumner fifty miles, the one locking in beyond the other to within five degrees. All the west coast of Kennedy Channel, up to Cape Lieber and Lady Franklin Sound, was clear of ice, with navigable water through the ice streams in the middle of the channel far to the northward. From Joe Island to the north, and east to Polaris Bay, the ice was clearly packed, but between Cape Lupton and Beechey was more open. Hurrying to the boat the ships were signalled to get under way, and we ran quickly to the northward across the channel under sail. Five miles north of Cape Lieber the pack obliged me to enter Lady Franklin. Sound, on the northern shore of which an indentation in the land gave promise of protection. On a nearer approach we discovered a large and well-protected harbour inside an island immediately west of Cape Bellot, against which the pack ice of the channel rested. Here the ships were secured close to the shore on the morning of August 25.

On entering the harbour we had the satisfaction of sighting a herd of nine musk-oxen, all of which were killed; our joy at the good luck of the sportsmen and ourselves being greatly increased by the news that the vegetation was considerably richer than that of any part of the coast visited by us north of Port Foulke, the Elysium of the Arctic regions. Finding that the harbour was suitable in every way for winter quarters, and the abundance of the spare Arctic vegetation in the neighbourhood giving every promise of game being procurable I here decided to leave the Disiovery, and to push forward with the Alert alone.

Owing to our high northern position, although the sun was still above the horizon at midnight, its altitude at noon was too low to affect the temperature much, consequently, after August 20 the temperature of the air remained steadily below freezing point for the winter, and the young ice was forming at midday much earlier than it does in more southern latitudes. Notwithstanding this, Arctic navigation depends so much upon the wind, that I considered that the transient.Arctic season of twenty days' duration was still at its height. The ice in Robeson
Channel was well broken up, moving up and down the strait with the change of tide, and only waiting for a wind to open a passage along shore.

Having strengthened my crew by embarking Lieut. Wyatt Rawson and seven men belonging to the Discovery, forming one travelling sledge party, on the morning of August 26 the two ships forming the expedition, the officers and crews of which had worked so harmoniously and successfully together, separated; those embarking in one, if the published charts and the statements of our predecessors proved correct, having the cheering feelings of in all human probability successfully completing the chief task assigned us, but the others, although elated at the prospects of their comrades and partaking generally in the inspiriting feelings, having a desperate fight to conquer the sensation of being left behind to play what they could not but consider a secondary part in the general programme.

On arriving at the entrance of the harbour the main pack was found to have closed in against the shore and completely filled up Lady Franklin Sound, some small floes streaming rapidly into Discovery Bay. In endeavouring to keep the ship clear of these, she touched the ground at the top of high water and hung there for half an hour, when, fortunately, by lowering the boats and lightening the ship a little, she floated again without damage. During the afternoon, at low water, the pack, which, apparently uninfluenced by wind, had been moving to the southward the whole day, but fastest during the flood tide, drifted slightly off the land. Immediate ad. vantage was taken of the welcome opening which enabled us to proceed north, but on reaching Point Murchison, the pack extending completely across the strait, prevented all farther progress ; there was therefore nothing for it but to return to "Discovery Harbour," where the ship was again secured at the entrance ready to advance at the first opportunity.

On the 27th we experienced very light north-east winds. The ice in the channel continued to move to the southward, except during the height of the ebb tide, when it was either stationary or set slowly northward, but not sufficiently so to open a navigable passage, although just before high water it appeared so ready to move that I was induced to recall the skating parties to the ship and keep the steam up. On the 28 th the ice was decidedly more open, and we were just about to move at II A.MI, the commencement of the north running tide, when a thick fog enveloped us, and, hiding everything at more than twenty yards distance, effectually prevented our moving. Later in the afternoon it cleared off, but it was now low water, and on trying to move the ship I found that, although afloat, she was within a basin, surrounded on all sides by a raised embankment of mud, so, with the tantalising prospect of an open channel before us, we were forced to remain until the rising water enabled the lightened ship to pass over the obstacle. Hoisting up the boats and signa!ling a final "good-bye" to the Discovery, we succeeded in advancing to within a mile of Cape Beechey, fifteen miles north-east of Discovery Bay, when, in a tussle with a heavy floe-piece, the rudder-headwhich had been badly sprung some days before-became so injured that the rudder was nearly useless; at the same time the pack was sighted pressing tight in against the cape on the northern side; I therefore secured the ship inside some grounded ice and shifted the rudder. While waiting at this part of the coast the sportsmen were fortunate enough to capture three more musk-oxen, a very welcome addition to our supply of fresh meat.

On the 29th the pack remained closed in to the northward of Cape Beechey until noon, when, at about the time of high water, from the summit of the cape, I observed it opening. The ship was immediately signalled to advance, and, picking up my boat on the way, we succeeded in reaching Lincoln Bay, but not without having to run an 
exciting and rather anxious neck-and-neck race with a heavy floe, which setting in towards the beetling precipitous cliffs of Cape Frederick VII., forming the south point of the bay, threatened to prevent our progress. At the entrance of Lincoln Bay, which otherwise is much exposed, some very heavy floe-bergs were aground on a bank, and they must to a great extent keep heavy ice from forcing its way into the bay during a south-easterly wind, in which direction the bay is perfectly open. The head of the bay, which appeared from the distance to be well vegetated, was filled with pack ice consisting of numerous small floe pieces less than a quarter of a mile in diameter, intermixed with "rubble," or "boulder" ice, now all cemented so firmly together with this season's frost that we had great difficulty in clearing away a dock for the ship.

On the zoth a depôt of provisions of 1,000 rations, for the use of travelling parties, was landed on the north shore of the bay. Soon after high water, the ice having opened out considerably, we proceeded to the northward; but, in doing so, some large floe pieces of unusually heavy ice obliged me, much to my regret, to stand out some three miles from the land, thereby risking the ship being beset in the pack which I was most anxious and careful to avoid happening. On all occasions of viewing the ice in Robeson Channel, since it was first seen. from Cape Morton, I had invariably noticed lanes of water stretching south-east and north-west across the channel from about Cape Lupton on the Greenland shore, to Cape Frederick VII. on the west side, due probably to this being the narrowest part or neck of the channel, and the ice jamming across the narrowing space north and south of it, according to the direction of pressure. Consequently, when at 3 P.M. the ice prevented any farther advance, observing many pools of water near us, and having two hours of the north-running tide favoured by a light air still due, instead of returning to the safety of Lincoln Bay, I waited at the edge of the pack, in the hope of its opening. But in this I was disappointed, for at 4 P.M., having just sufficient warning to enable me to pick out the safest-looking place ncar us, that is, to get as far away as possible fiom the heavy ice, it completely encircled the ship, and she was hopelessly beset in a very heavy pack, consisting of old floes of 80 feet in thickness, and from one to four miles in diameter, the intervals between them filled with broken. up ice of all sizes, from the blue-ice rounded bummocks which were sufficiently high above the water-line to lift the quarter boats bodily as they passed underneath, whilst grinding their way along the ship's side, down to the smaller pieces which the previous nipping together of the heavy floes had rounded and polished like the boulders and pebbles in a rapid river. Intermixed with the pack, fortunately for us, was a vast collection of soft pats of slucige-ice formed during the last snowfall: this, if squeezed together before it is properly hardened into ice, forms into plate-like masses with raised edges, each piece, whenever moved, assisting to round its neighbour.

Since meeting the ice off Cape Sabine I had noticed a gradual but considerable change taking place in the appearance and formation of the floes. The beaviest that we first encountered were not more than eight or ten feet in thickness. Off Cape Frazer were a few more ancient pieces, estimated at the time as being twenty feet thick, but we now know that that was far short of the correct measure. But up to the present time, when the main pack consisted of heavy ice, I had failed to realize that, instead of approaching a region favoured with open water and a warm climate, we were gradually nearing a sea where the ice was of a totally different formation to what we had ever before experienced, and that few Arctic navigators had met, and only one battled with successfully; that in reality we must be approaching the same sea which gives birth to the ice met with on the coast of America by Collinson and McClure, and which the latter in $185 \mathrm{I}$, succeeded in navigating through in a sailing vessel for upwards of 100 miles, during his memorable and perilous passage along the north-west coast of Banks Land, from Prince Alfred Cape to the Bay of Mercy, but there sealed up his ship for ever; which Sir Edward Parry met with in the same channcl in 1820 , but with the more difficult task before him of navigating against stream and prevailing wind, was forced to own conquered even him and his experienced companions; which, passing onwards to the eastward down McClintock Channel, beset, and never afterwards released, the Erebus and Terror under Sir John Franklin and Captain Crozier ; and which, intermixed with light Spitzbergen ice, is constantly streaming to the southward along the eastern shore of Greenland, and there destroyed the Hansa of the German Arctic Expedition.

As our only hope of pushing north against the general set of the current, to say nothing of the extreme hazard of remaining in such a pack, consisted in regaining the shore, both boilers were lighted and full steam kept ready, in order to take immediate advantage of any opportunity that might occur. During the night, at the top of high water, the pack, which previously had been drifting in a compact body to the southward, eased a little near the edge of the large and deep floating floes, in consequence of a difference in the force of the surface and under-current ; but before we were able to clrar away a space of water at the stern sufficiently large to cnable the rudder to be shipped, the ice closed, and obliged us to dismantle again. At the full height of the ebb current the pack again tried its best to open, but with the same result.

Fully expecting a change at low water, with much iabour a working space was cleared under the stern, but owing to the spare rudder being very badly balanced we nearly lost our opportunity. At last, with the same riomentary slacking of the ice pressure as occurred at the top of high water, with a greater pressure of steam than had been exerted even during the official steam trial, the ship commenced to move; when, by advancing and retreating, a water space was gradually formed in which the ship couid gain momentum, and at last we pushed our way bodily into ice not quite so close, and succeeded most providentially in reaching the shore in Lincoln Bay. Had we been delayed another five minutes the ship would have been caught in the pack during the heavy gale which set in from the south-west the same evening, and continued for two days; and which, in fact, by forcing the pack to the north-east, out of the Robeson Channel, enabled the ship to pass Cape Union without any trouble.

During the late struggle, as well as on many previous occasions, it was noticeable how futile the efforts of the crew were to clear away the ice on the bow or quarter which impeded the movement of the ship, compared to the enormous power exerted by the ship when able to ram her way between the pieces even at ordinary speed. Thus steamers are enabled to penetrate through a brokenup pack which the old voyagers, with their sailing vessels, necessarily deemed impassable. At the same time there is a limit to the risks which are advisable to be run; no ship has yet been built which could withstand a real nip between two pieces of heavy ice:

On the afternoon of August 3I, shortly after the ship was secured in her former position to the firm ice in Lincoln Bay, the wind gradually freshened from the south-west, blowing slightly off the land, accompanied with a snowstorm and a threatening appearance of the weather. So far as we could $d$ :stinguish through the snow, the main pack was driven by the gale to the northward up the channel, but knowing that it would take some hours to produce a navigable passage past Cape Union, I waited until the morning of September $x$, when with steam at hand ready if requisite, we passed up the straits, running before a strong gale $9 \frac{1}{2}$ knots an hour, between 
the western shore and the pack, which was driving quickly to the northward, at about three miles distance from the land. By noon, having carried Her Majesty's ship into latitude $82^{\circ} 24^{\prime} \mathrm{N}$., a higher latitude than any vessel had ever before attained, the ensign was hoisted at the peak. On hauling to the westward at the northern entrance of Kobeson Channel, we lost the wind under the lee of the land, and were obliged to furl sails and proceed under steam; at the same time the breadth of the navigable water channel was much contracted, until off Cape Sheridan the ice was observed to be touching the shore.

In Robeson Channel proper, except where the cliffs rise precipitously from the sea, and afford no ledge or step on which the ice can lodge, the shore line is fronted at a few paces distance by a nearly continuous ragged-topped ice wall from fifteen to thirty-five feet high. It is broken only opposite the larger ravines, where the soil carried down by the summer flood has, by accumulating, shallowed the water sufficiently to catch up the drifting ice as it passes, and form a line of more isolated ice bummocks. Here the continuity of the ice wall is occasionally broken. But on leaving Robeson Channel, immediately the land trends to the westward, the coast line loses its steep character, and the heavy ice is stranded at a distance of 100 to 200 yards from the shore, forming a fringe of detached masses of ice from 20 feet to upwards of 60 feet in height above water, aground in from eight to twelve fathoms water, and except where the coast is shallow extending close into the beach line. The average measurement of the ice in thickness as it floated is So feet, and it always breaks from the salt water floe of which it originally formed a part in pieces of slightly greater dimensions in horizontal measurements. On finding the ice close in at Cape Sheridan, having made good 25 miles of northing since leaving Lincoln $B$ ay in the morning, my only alternative was to secure the ship inside this protecting barrier of ice, where she was accordingly placed during the afternoon, and a depôt of provisions of 2,000 rations established for the use of travelling parties. The weather remained thick until the evening, when I obtained a good view from a station abont 300 feet above the sea level. 'The coast line continued to the north-west for about thirty miles, forming a large bay bounded by the United States' range of mountains--Mounts Marie and Julia and Cape Joseph Henry, named by the late Capt. Hall, are so conspicuous that it was impossible to mistake their identity although more than thirty degrees out in bearing on the chart. No land was to be seen to the northward although our wishes leading to the thought, we still hoped that the heavy clouds in that direction might hide it from our view. But considering the character and movement of the ice $I$ was reluctantly forced to admit that it gave convincing proof that none existed within a reasonable distance, and that we had arrived on the shore of the Arctic Ocean finding it exactly the opposite to an "Open Polar Sea." The pack ice extended close in to Cape Sheridan and the shore to the westward of it, a pool of water being noticed on the east or lee side of each projecting point in the bay which the intervening ice effectually prevented our thinking of reaching. To the eastward the channel by which we had advanced was completely blocked by the return of the ice, and the ship, although fairly protected, was thoroughly embayed by the pack. The last snowfall had covered the land completely to a depth of from 6 to 12 inches and the low sloping hills formed anything but a cheering landscape.

During the night the wind again freshened considerably from the south-west, and in a squall carried away the hawsers by which we were secured and obliged me to let go a bower anchor; this falling on gravel did not bring the ship up until she had drifted half a cable's length outside the barrier of "floe-bergs" from which the pack was slowly retreating twwards the north-east. The gale continued all night and drove the pack two miles off shore, but its constant motion to the eastward kept it tight in against Point Sheridan and cut us off from all chance of advancing. I was much struck at the time by the pertinacicy with which the pack kept its ground during this severe gale, and could not help fearing that there would be little chance of its opening out sufficiently to allow us to advance much farther this year; but knowing well the occasional inexplicable uncertainty in its movements we still hoped for the best.

On the morning of September 2 the wind suddenly shifted from south-west to north-west, bringing the pack rapidly in to wards the land, and causing the ship to swing broadside on to the heavy stranded ice; fortunately, the barometer having indicated the probability of a change occurring, steam had been kept ready, and after a considerable amount of mancuvring the anchor was weighed. Our protected dock was so small, and the entrance to it so narrow and encumbered with ice, that it was with extreme difficulty, much labour, and no trifling expense in broker hawsers, that the ship was hauled in stern foremost, with the united force of the wind and flood tide pressing at right angles to the course. It was a nice question whether the ice or the ship would be in first, and my anxiety was much relieved when, as the whole northern pack reached the outside of our friendiy toebergs, I saw the ship's bow swing clear inside into safety, and the pack, instead of doing us an injury, considerably streligthen our protecting outwork by forcing new pieces on shore; at the same time, we could not help foreseeing that by so doing our chance of advancing when we wished was proportionately lessened. The danger we had so narrowly escaped from was forcibly represented to us all, as the pack, with irresistible force, swept past us to the eastward at the rate of a mile an hour, and constantly added to the accumulated masses outside.

The projecting point of a heavy floe would first ground in from ten to twelve fathoms of water; then the outer mass, continuing its course, unable to stop its progress, would tear itself away from its cast-off portion. The pressure, however, still continuing, the severed piece was forced, and frequently by the parent mass itself, up the steeply inclined shore, rising slorvly and majestically out of the water 10 or 12 feet above its old line of flotation, and remaining usually nearly upright. The motion was entirely different to that produced when two ordinary floes some 4 or 6 feet thick met together; then, the broken edges of the two pieces of ice, each striving for the mastery, are readily upheaved and continually fall over with a noisy crash. Here, the cnormous pressure, raising pieces, frequently 30,000 tons in weight, in comparative silence, displays itself with becoming solemnity and grandeur. What occurs when two 80 -foot floes mect we cannot say; but the result, as far as a ship is concerne $A$ floating as the ice does higher out of the water than herself, would be much the same as the closing together of the two sides of a dry dock on the confined vessel.

For the next three days we experienced light westerly winds ; the ice remained close in to the coast, moving generally to the south-eastward, but occasionally stopping and closing up towards the north-west during the ebb tide. During the flood, pools of water, half a mile long by a quarter broad, frequently formed on the south-east side of the larger floes, but they were always completely isolated from each other by several miles of heavy ice. Although a few large floes could be distinguished in the offing, the pack within five miles of the land usualiy consisted of floes of less than a mile in diameter, with a very large proportion of rubble ice evidently broken off the large floes as they forced their way past the points of land to the north-west of us, the whole forming as rough a road for sledge travelling as could well be imagined.

At this period, although all regular navigation was evidently at an end, I was naturally most anxious to move the ship from her exposed position before the setting in 
of winter, but the quickly advancing season warned me that no movement should be made without a reasonable probability of attaining a sheltered position. Accordingly, Commander Albert Hastings Markham and Lieut. Pelham Aldrich started on September 5 to look at a bay seen from our bill station about eight miles distant from us to the westward. They reported that it was a well-sheltered harbour, thickly coated with this season's ice, but that the continuous wall formed by the grounded floe-bergs across the entrance to it would effectually prevent our entering.

Afrer this report, with the temperature remaining steady between $+20^{\circ}$ and $+10^{\circ}$. and the barrier of grounded ice, which, although protecting, effectually imprisoned us, having increased in breadth to seaward for 200 yards, each heavy piece being compactly cemented in amongst its neighbours by the lighter broken up rubble ice, which was carried in by the tidal current, and frozen into position by the low temperature, I decided to commence landing such provisions and stores as were hampering the decks of the ship, and which would not be required during the winter, should we fortunately be able to move into safer quarters.

On September 6, 7, and 8, we experienced a heavy fall of snow, which, bearing down the young ice by its accumulated weight, allowed the water to percolate upwards, and render the floe very wet and unfavourable for travellins on. But not expecting any decided movement of the ice during the neap tides, and having secured the ship with a bower anchor and cable to the shore, and landed an ample depôt for the support of any travelling party in the event of accident to the ship, which at the time did not appear improbable, Lieut. Pelham Aldrich, accompanied by Capt. Feilden, R.A., and Dr. Edward L. Moss, started on a pioneering journey towards the north, and Lieut. Wyatt Rawson towards the south. The latter returned after two days' absence, having found the cape three miles from the ship, forming the entrance to Robeson Channel, impassable by land, on account of the steemness of the clifis; and by sea, in consequence of the continual movement of the broken pack, which prevented him venturing on it, even with a boat. Lieut. Aldrich's party returned after an absence of four days. He had succeeded in establishing a depôt of provisions, and exploring the coast line for a distance of twenty miles to the north-west. The travelling was found to be unusually heavy, owing to the very rough state of the ice, and the deep snow, with its sticky wet foundation of sludge; indeed, so bad was it that altbough only laden with half weights, ail three sledres broke down. The young ice in the few patches met with was too weak and treacherous to admit of heavy sledgis journeying over it ; one sledge broke through, and was only recovered with much diff. culty.

On September to a westerly wind blowing off shore, force 4 , combined with the ebb tide, opened for the first time since our arrival here, a narrow channel between the grounded ice and the pack extending for half a mile beyond Cape Sheridan, but trending out to seaward. On the I Ith, the same wind continuing, the channel widened out until it was a mile broad, and extended for six miles to the westward, ending two miles distant from the shore. As this offered an opportunity of advancing a large depôt of travelling provisions and boats by water, Commander Markham started with a strong party, having first to launch the boats across the heavier barrier of ice within which the ship was sealed up, apparently frozen in for the season.

The sky being fairly clear, this was the first day on which we were able to pronounce decidedly concerning the northern land reported to exist by the Polaris. After a constarit watch, and carefully noting the movement of the darkened patches, I was now with much reluctance forced to admit that no land existed to the northward for a very considerable distance. As seen through the light haze the dark reflection of the sky above the detached pools of water in the offing, in strong contrast by the side of the light reflected from the close ice, which in a great measure is similar to the bright glare reflected from a large sand flat, creates a very decided appearance of land when there is a mirage; indeed, sufficiently so as to deceive many of us when so anxiously cxpecting and hoping to see it. We, therefore, cease to wond $r$ at the casual look-out men from the Polaris being mistaken, but the more experienced on board should not have allowed themselves to be so readily misled.

During the $\mathrm{I} 3^{\text {th }}$ and $\mathrm{I} \mathrm{z}^{\mathrm{t}} \mathrm{th}$ the wind from the southwest gradually freshened, until on the latter day it was blowing a very strong gale, force 10 in the squalls, and evidently extending over the whole extent of Kennedy Channel; for the swell from the open water which it had producet on the weather shore extended round Caoe Rawson, and reaching our position broke up all the light ice formed this season, and drove it out to sea, the larire grounded floe-bergs alone remaining, with clear passages between them, through which we could have readily passed if requisite; but the main pack to the westward, although the channel leading to seaward had extended to between ten and twelve miles distance from us, still remained fast to the shore at a distance of about six miles from the ship.

The ship was secured by a bower cable, stern to the shore, one side resting against a large floe-berg, and bumping slightly against it with the swell. During the evening it was blowing furiously, with a blinding snowdrift, and whilst I was thinking of the uncomfortable state of the travellers in the tents in such a gale, I observed Commander Markham arrive abreast the ship. Although we were within I 20 yards of the shore, it was only by double manning the oars of the cutter that during an opportune lull I was able to establish a hauling line between the ship and the shore, and so communicate with him; when it appeared that, having one man disabled from exhaustion, he had decided to push on for the ship to obtain assistance. With the help of the fresh meu forming the cutter's crew, Capt. Markham and myself had the satisfaction of seeing the sledge party all on board befrre midnight, and the frozen man's life saved; but the sledge crew, who had so gallantly faced the storm, were all mnch exhausted, and in fact did not recover themselves for several days.

On the morning of the $5^{\text {th }}$ the wind lulled considerably, and the remainder of Commander Markham's party, under the command of Lieut. Parr, returned, having passed ary thing but a pleasant time in their tents during the gale. On ascending our look-out hill I observed that the ice to the westward between the land and the channel in the pack liad dritted to seaward, leaving a clear road by which we could advance to a place of shelter. Making a signal to the ship, steam was immediately got ready and the rudder shipped, but on lowering the screw we found it impossible to enter the shaft. Whilst raising it again to clear away the ice, a very thick snowstorm came on with a blinding mist, which, hiding everything from view, prevented our moving. Before midnight the storm was blowing as furiously as ever.

On the morning of the 16 th, the gale still keeping the main pack clear of the shore, the weather cleared asain, and another attempt was made to ship the screw, but without success, on account of the accumulated ice. While endeavouring to clear it the wind gradually shifted round to the north-west, and we had the mortification of seeing the pack rapidly nearing the land. By 2 P.M. it had reached the shore ice, and effectually closed us in for the winter. It never left the shore to the north-westward of our position afterwards, although a large space of clear water remained to the eastward between us and Robeson Channel, so long as the wind lasted from the eastward. 
I may here add that on examining the coast-line afterwards, both during the autumn and the following spring, I am firmly persuaded that our forced detention during the late gale was most providential. There was no bay on the coast open enough to receive the ship, and the ice at the entrance of each was far too thick for us to cut or force our way through before the main pack had closed in.

Off the open coast where we were forced to pass our winter, the heavy nature of the ice constituted our safety; grounding in twelve fathoms, it was impossible that it could hurt the ship. At first I was rather anxious lest any lighter ice might be forced in, and that then the ship might be driven by it on shore, but as time advanced and nothing but ice of the same thick character made its appearance, I became more reconciled to our position. It ultimately proved to be the best sheltered position on the coast from which a ready means of retreat was likely to be offered. In all other parts, the beach, either by being too steep, allowed the heavy ice to force its way close up on to the shore, or where shallower, left a sufficiently large space of water in which smaller and more dangerous ice-blocks were able to drift about before they grounded in about the same depth of water as that in which the ship floated.

During the following week preparations were made for the autumn sledging, each man being fully employed fitting his travelling clothing and preparing the equipment of the sledges. As soon as the shore ice was sufficiently strong, Commander A. H. Markham, with Lieutenants A. A. C. Parr and W. H. May under his orders, started on September 25 with three sledges to establish a depôt of provisions as far in advance to the north-westward as possible. Licut. P. Aldrich left four days previously with two lightly-equipped $\mathrm{dog}$ sledges to pioneer the road round Cape Joseph Henry for the larger party. He returned on board on October 5, after an absence of thirteen days, having been accompanied by Adam Ayles, A.B. On September 27, from the summit of a mountain 3.000 feet high, situated in lat. $82^{\circ} 48^{\prime}$ N., somewhat further north than the most northern latitude attained by our gallant predecessor, Sir Edward Parry, in his celebrated boat journey towards the North Pole, he discovered land extending to the north-westward for a distance of sixty miles to lat. $83^{\circ} 7^{\prime}$, with lofty mountains in the interior to the southward. No land was sighted to the northward.

On October I 4 , two days after the sun had left us for its long winter's absence, Commander Markham's party returned after a journey of nineteen days, having, with very severe labour, succeeded in placing a depôt of provisions in lat. $82^{\circ} 44^{\prime} \mathrm{N}$, and in tracing the coast-line nearly two miles further north, thus reaching the exact latitude attained by Sir Edward Parry. Being anxious to inform Capt. Stephenson of our position, and the good prospects before his travelling parties in the following spring in exploring the north-west coast of Greenland, I despatched Lieut. Rawson again to attempt to open communication between the two vessels, although I had grave doubts of his succeeding. He was absent from October 2 to October 12 , returning unsuccessful on the latter day, having found his road again stopped by unsafe ice within a distance of nine miles of the ship. The broken masses of pressed-up ice resting against the cliffs, in many places more than 30 feet high, and the accumulated deep snow-drifts in the valleys caused very laborious and slow travelling.

During these autumn sledging journeys, with the temperature ranging between $15^{\circ}$ above and $22^{\circ}$ below zero, the heavy labour, hardships, and discomforts inseparable from Arclic travelling, caused by the wet soft snow, weak ice, and water spaces, which obliged the sledges to be dragged over the hills, combined with constant strong winds and misty weather, were, if anything, much greater than those usually experienced. Out of the northern party of twenty-one men and three officers, no less than seven men and one officer returned to the ship badly frostbitten, three of these so severely as to render amputation necessary, the patients being confined to their beds for the greater part of the winter.

The sledges with their cargoes on four occasions broke through the ice, and individual men frequently; but these, becoming wet through, were made to change their clothing, and so escaped any bad consequences. The frost-bites are to be attributed entirely to the wet sludgy state of some of the ice that had to be crossed. It so happened that heavy snow fell on twelve consecutive days, forming a layer of lightly compressed snow at least 2 feet thick, which in the snow-drifts collected into ridges more than double that depth. The thin ice, not being sufficiently strong to support this additional weight, became borne down and allowed the water to ooze through. This being protected from the cold temperature of the air by its blanket-like covering, remained unfrozen, although the temperature was upwards of $40^{\circ}$ below the freezing-point ; consequently whenever the travellers, inexperienced as they were at the time, were forced to drag their sledges over a road of this nature, their feet became wet and afterwards frost-bitten a considerable time before they discovered it (when the tent was pitched in the evening), by which time the mischief had attained such an advanced stage as to defy all restoration of the circulation. The tent equipment became so saturated with frozen moisture that on arrival on board it weighed more than double, what it did when dry before starting; and so anxious were all to escape another sleepless night in the stiffly frozen blanket bags, that on the last day a forced march was made by the northern party through the heavy snow to the ship, in which the powers of endurance of all engaged were tried to the utmost. All the travellers returned in wonderful spirits and full of pluck. Nothing could exceed the determined perseverance with which each obstacle to the advance of the party was overcome, or the cheerfulness with which each made light of the numierous unavoidable hardsbips they had undergone. The sledges proved to be too rigid; the uprights breaking necessitated frequent stoppages for repairs; but by taking out the metal pins connecting them to the upper bearers, and depending upon the hide lashings, they afterwards stood the unusually heavy work admirably.

On no one day while the northern party were travelling this season could they have obtained snow of sufficient consistency to enable them to build snow houses for shelter by night. Lieut. Rawson, finding harder snow in the southern ravines, was able to construct a snow house on one occasion. The advantageous results of the autumn travelling, in addition to the advance of provisions for future use, were, first, a considerable gain in experience in Arctic sledging, and secondly, by our greater good fortune in finding continuous land over or near which to travel, we succeeded in wresting from Sir Edward Parry and his companions their gallantly-achieved distinction of having advanced the British flag to the highest northern latitude. I have grouped the names of himself and his followers together on the chart in the latitude to which they attained in 1827 . On the return of the travelling parties, the sun having bidden us farewell, preparations were made for the winter; the ship was housed over, all the provisions and stores which could withstand the weather, and for which room could not be found below hatches, were deposited on shore, and the habitable deck cleared as much as possible. By carefully covering over the engine-room hatches with a thick layer of snow, the cold, throughout the winter, was kept from penetrating downwards into the lower part of the ship. The temperature of the holds and engine-room, without the use of fires, always remaining above +28.5 , the temperature of the surrounding water, and the fire-pumps which had 
their suction pipes more than six feet below the water-line, remained serviceable to the last.

The long Arctic winter, with its unparalleled intensity and duration of darkness produced by an absence of sunlight for 142 days, was passed by each individual on board with much cheerfulricss and contentment. Owing to the sameness in the daily routine, which, when looking into futurity, is thought to entail a long duration of dreasy monotony, the time, in reality, passed with great rapidity, and in January, when the first glimmering increase in the midday twilight began to lengthen sensibly day by day, the want of light was scarcely noticed by any one; and not until the sun actually returned on March $\mathrm{I}$ did we in any way realise the intense darkness we must have experienced for so long a period. The manifold ordinary duties of the ship-to which were added the constant repair of the snow embankment, which, in conscquence of our being frozen in close to a stranded piece of ice, was thrown down every spring tide-kept the ship's company fully employed, and gave them plenty of exercise during the day. On five evenings in the week a school, formed on the lower deck under Commander Markham and several of the officers, was well attended, each Thursday being devoted to lectures, songs in character, and readings, with occasional theatrical representations ; the whole so admirably arranged and conducted by Commander Markham as to keep up the pleased interest of all for the whole period. The ventilation of the ship received the unceasing attention of Dr. Thomas Colan and myself, and owing to the large extra space amidships, left little or nothing to be desired in that respect. The health of the officers and crew, with only ore exception, was most excellent, and the habitable deck as dry as is possible in these regions, in a ship without an extraordinary expenditure of coal.

With the arrival of the new year preparations for the spring travelling campaign commenced, the dogs being excrcised daily under the superintendence of Mr. George Le Clere I gerton, Sub-Lieutenant, as soon as there was sufficient light. The pack in the offing remained in motion until the first week in November, when it gradually settled itself into position for the winter, the last pool of water being seen on the 16 th of the month off Cape Rawson at the entrance to Robeson Channel. No movement, whatever occurred in the ice during the winter, except the formation of a tidal crack outside the grounded ice, which opened 2 or 3 feet during the spring tides. Although we had trequent evidence of strong winds prevailing in Robeson Channel, the weather at our winter quarters was remarkably calm; indeed we may be said to have wintered on the border of a Pacific Sea. The prevailing $\mathrm{wind}$ was from the westward; we never experienced any easterly winds; it always blew off the land. $\mathrm{Had}$ it not been for the intervening calms, the persistent westerly winds might have been well called a trade wind. On only two days were we prevented by the wind and accompanying snow-drift from taking exercise outside the ship. This quiet state of the atmosphere was productive of the severest cold ever experienced in the Arctic regions.

Early in March, during a long continuance of cold weather, the Alert regisiered a minimum of 737 below zero; the Discovery, at the same time, $70^{\circ} 5$ below zero. In I 850 the North Star, at Wolsenholme Sound, in lat. $76^{\circ} 30^{\prime}$ N., recorded 69.5 below zero. The Alert's minimum temperature for tuenty-four hours was 7031 below zero, the Discovery's minimum temperature for twenty-four hours was $67^{\circ} \circ$ below zero; Dr. Kane's, at Rensselaer Harbour, in lat. $78^{\circ} .37^{\prime} \mathrm{N}$. in $1854,5^{\circ} 01$ below zero. Proviously the longest continuance of cold weather recorded, that by Sir Edward Belcher at Northumberland Sound, in lat. $76^{\circ} 52^{\prime}$ N., in 1853 , was a mean temperature for ten consecutive days of $4^{\circ} 9$ below zero. The Duscovery experienced a mean temperature for seven consecutive days of 58.17 ditto. The Alert experienced a mean temperature for thirteen days of 58.9 ditto; and for five days and nine hours of 66:29. During February mercury remained frozen for fifteen consecutive days; a south-westerly gale, lasting four days, then brought warmer weather ; inmediately the wind fell cold weather returned, and the mercury remained frozen for a further period of fifteen days.

After the heavy snow-fall in the autumn previously alluded to, very little fell, and much trouble was experienced in obtaining sufficient for embanking the ship, it being necessary to drag some from the shore for that purpose. Owing to the small quantity which fell during the winter, estimated at from 6 to 8 inches, the summits of the coast hills were uncovered by the wind and remained so until May and the early part of June, when we again experienced a heavy snow-fall, estimated at a mean thickness of $I$ foot. In the valleys and on the shores having an eastern aspect, the snow which fell remained light, and, unless snow-shoes were used, caused very heavy travelling. In the unprotected valleys and on the weather coasts the snow was sufficiently compact to afford fair travelling, much the same as that experienced in southern latitudes, where the more variable winds harden the snow every where.

Light flashes of aurora were occasionally seen on various bearings, but most commonly passing through the zenith. None were of sufficient brilliancy to call for notice. The phenomena may be said to have been insignificant in the extreme, and, as far as we could discover, were totally unconnected with any magnetic or electric disturbance.

During the winter Commander Albert $H$. Markham and Lieut. George A. Giffard employed themselves with much diligence and perseverance at the magnetic observatory, situated on shore, in a series of large and lofty snow houses, which were connected together with a covered snow gallery. Weekly observations were made with Barrow's dip circle for determining the inclination, and by means of Lloyd's needles for the total (relative) force. Occasionally these observations were repeated on the same day. The absolute horizontal intensity was obtained once every three weeks, and a series of hourly differential observations were obtained with the portable declination magnetometer on several consecutive days in the months of December, January, and February. At various places between Disco and the Alert's winter quarters, whenever opportunities offered, observations for inclination and total force were taken with Mr. Fox's instrument, observations for determining the absolute declination were also taken when opportunities occurred.

Lieut. Pelham Aldrich superintended the meteorological observations, also observations with Sir C. Wheatstone's polariscope, and Lieut. Alfred A. C. Parr, notwithstanding the severe season, obtained a good series of astronomical observations, also observations with the spectroscope and Sir William Thomson's por:able electrometer.

I have not hitherto alluded to the services of Capt Feilden, Paymaster, R.A., Naturalist to the Expedition, preferring that the report on the numerous scientific subjects to which he has directed his attention should emanate from himself; I will merely state here that not one moment has been lost by this indefatigable collector and observer. He has, moreover, by his genial disposition and ready help on all occasions, won the friendship of all, and I feel confident that their Lordships will Lighly appreciate his valuable services. I am only doing him justice when I state that he has been to this expedition what Sabine was to that under the command of Sir Edward Parry.

Dr. Edward Moss, a highly skilled and ta!ented observer, in addition to his medical duties. kept hinself iully employed in many branches of natural science; his investigations embraced studies of the floe-bergs and floes, 


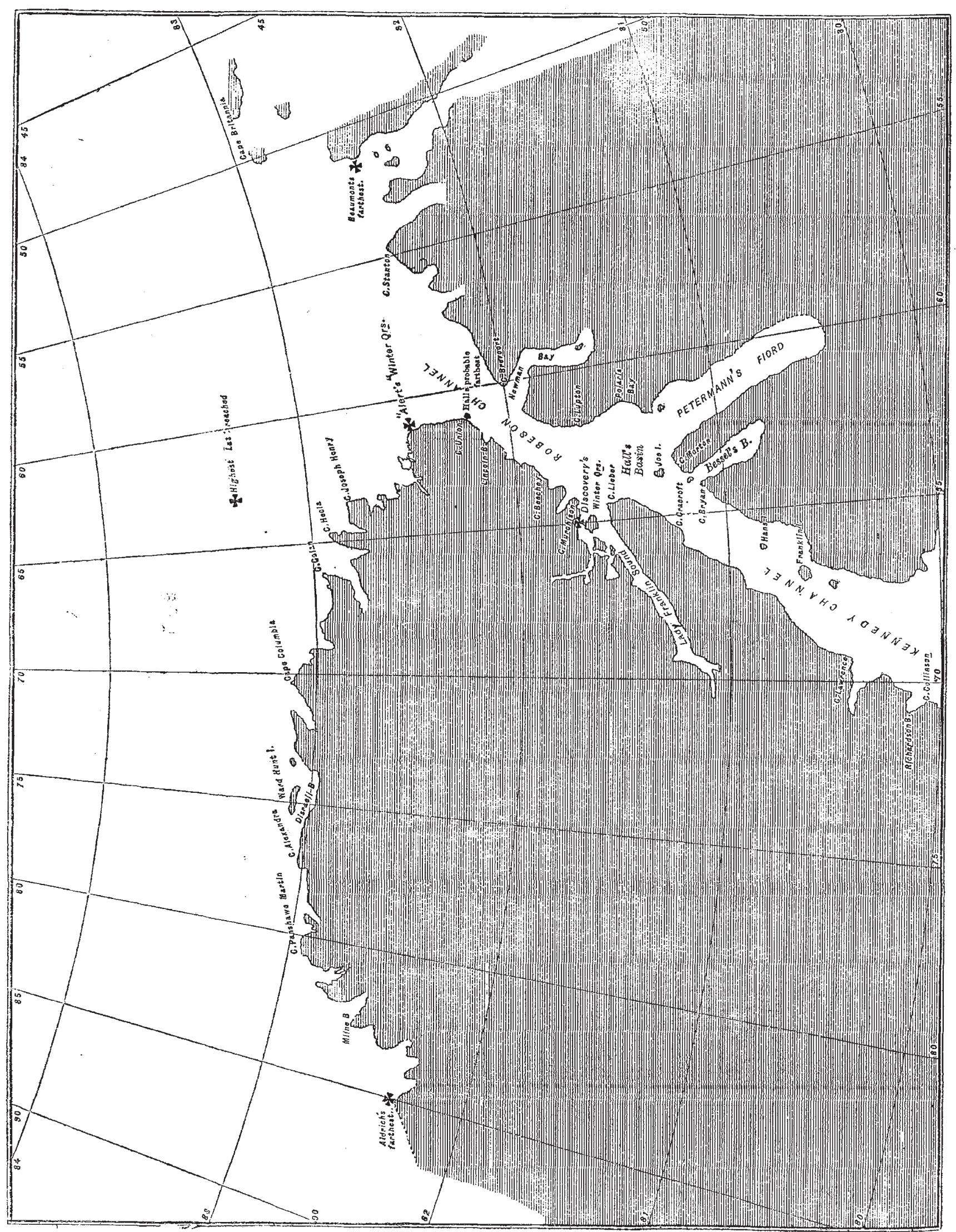


principally chlorine estimations, specific gravity estimations by Buchanan's method, and microscopy of dust strata; the chlorine and specific gravity estimations, and the microscopy of winter sea water; examination of air precipitates; estimation of carbonic acid and watery vapour in air ; some experiments on the brittleness of iron at low temperatures.

The vicinity of our winter quarters proved to be unfavoured by game. On our first arrival a few ducks were seen and five shot, and during the winter and spring three hares were shot in the neighbourhood of the ship. This completes our list up to the end of May. In March, a wolf suddenly made his appearance, and the same day the tracks of three musk-oxen or reindeer were seen within two miles of the ship, but they had evidently only paid us a flying visit. In July six musk-oxen were shot, the only ones seen in our neighbourhood. The travelling parties were only slightly more fortunate in obtaining game. In June a few ptarmigan, ducks, and geese were shot and used by the sick. In July and August they obtained a ration of fresh meat daily. In March and the beginning of April about two dozen ptarmigan passed the ship, flying towards the north-west in pairs; finding no vegetation uncovered by snow in our neighbourhood, they flew on seeking better feeding grounds; they were nearly all shot subsequently by the outlying parties near Cape Joseph Henry. In the middle of May snow-buntings and knots arrived. A number of the young of the latter were killed in July, but no nests or eggs were found. Early in June ducks and geese passed in small flocks of about a dozen, flying towards the north-west, but owing to a heavy fall of snow, lasting three days, which covered the land more completely than at any other time during our stay, at least half the number returned to the southward, not pleased with their prospects so far north. Two dozen small trout were caught during the autumn and summer in lakes from which they could not possibly escape to the sea.

The total game list for the neighbourhood of the Alert's winter quarters, is as follows :-

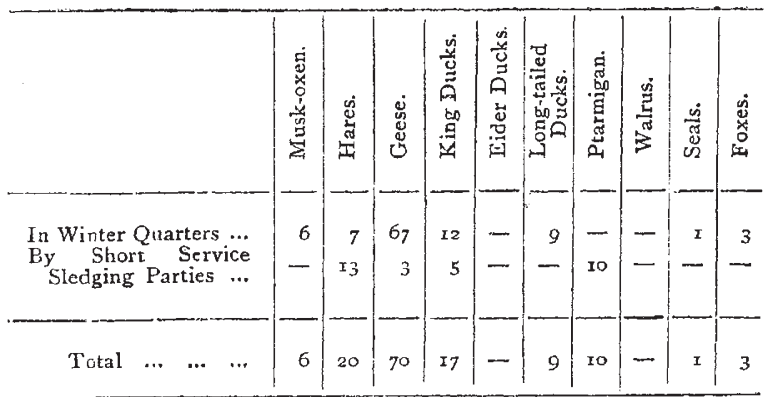

On March I the sun returned after its long absence.

The sledging season being now near at hand, I prepared orders for Capt. Stephenson to employ the whole force at his disposal in exploration of the neighbouring shore and the north coast of Greenland, instead of sending a party to communicate with Smith's Sound, as I considered that a sledge party employed on that duty this season would be performing unnecessary work, and that in the event of their Lordships communicating with Littleton Island, and finding that I had not visited it, they would understand that the expedition was well placed for exploration far north, and that all was going on satisfactorily.

March 4 was the day fixed for the dog-sledge to start to open communication with the Discovery, should the weather be favourable, but the severe cold which we then experienced prevented their starting. The temperature remained unusually low until the 12 th, when it rose to $-35^{\circ}$, and the weather being fine and settled, Mr.
George Le Clere Egerton, Sub-Lieutenant, started in charge of the dog-sledge, accompanied by Lieut. Wyatt Rawson, belonging to the Discovery, whom I wished to consult with Capt. Stephenson concerning the exploration of the Greenland coast, and Christian Petersen, interpreter. As I knew that this journey was sure to entail very severe labour, Frederick, the Esquimaux dog-driver, not being a strong man, was left on board. Four days afterwards, the temperature having risen considerably in the interval, with a strong wind from the southward, the party returned in consequence of the severe illness of Petersen. He was taken ill on the second march with cramp in the stomach ; and afterwards nothing could keep him warm. The tent being very cold, the two officers burrowed out a snow hut, and succeeded in raising the temperature inside to $+7^{\circ}$, but the patient still remained in an unsatisfactory condition, and it was only by depriving themselves of all their own warm clothing, and at the expense of the heat of their own bodies, that they succeeded, after great persistence, in restoring the circulation in his extremities to some extent. The following day, Petersen being no better, they wisely determined to return with him immediately to the ship. During this journey of sixteen miles, both Mr. Egerton and Lieut. Rawson behaved most heroically, and, although frequently very seriously frost-bitten themselves, succeeded in keeping life in the invalid until they arrived on board. He was badly frost-bitten in the feet, both of which had subsequently to be amputated. Notwithstanding the professional ability and incessant watchful care of Dr. Thomas Colan, he never recovered from the severe shock his system had received on this occasion, and eventually expired from exhaustion three montbs afterwards. He leaves a wife and family living in Copenhagen, who I trust will receive a pension.

On March 20, with fine weather and a temperature of $30^{\circ}$ below zero, Mr. Egerton and Lieut. Rawson, having partially recovered from their most praiseworthy exertions when attending Petersen, again started for the Discovery, accompanied by two seamen, which they succeeded in reaching on the sixth oay, after a very hard scramble over the rough ice in Robeson Channel, and along the steep snow slopes formed at the foot if the precipitous coast cliffs. No water was met with beyond that formed in the tidal crack, close to the shore. The temperature throughout the journey ranged from $42^{\circ}$ to $-24^{\circ}$. During the latter part of March the sledge crews were fully employed preparing their provisions, and equipping the sledges for the spring journeys. Long walks were taken for exercise, and a depôt of provisions was placed a few miles to the southward for the use of the Greenland division.

On April 3 the seven sledges and crews, numbering fifty-three officers and men, started on their journeys with as bright prospects before them as any former Arctic travellers-everyone in apparently the best possible health, and, while knowing the severe labour and hardships they would have to undergo, all cheerful, and determined to do their utmost. A finer body of picked men than the crews of the three extended sledge purties was never previously collected together.

Commander Albert H. Markham, seconded by Lieut. Alfred A. C. Parr, with two boats equipped for an absence of seventy days, was to force his way to the northward over the ice, starting off from the land near Cape Joseph Henry.

Three sledge crews, under the respective commands of Dr. Edward Moss, who in addition to his duties as Medical Officer to the division, volunteered to assume executive charge, and Mr. George White, Engineer, also a volunteer, accompanied them as far as their provisions would allow. Lieut. Pelham Aldrich, assisted by a sledge crew under the command of Lieut. George A. Giffard, was to explore the shores of Grant Land towards the north and 
west, along the coast line he had discovered in the previous autumn.

In regard to the first of these two journeys, that undertaken over the ice towards the north, it is my duty to its Commander and his followers to state that, knowing the extremely rough road over which they would be obliged to travel, I had little hope that they would reach a high latitude, for their daily progress with light or heavy sledges must necessarily be very slow. I thought it best, nevertheless, to make the experiment, to prove whether or not the Pole could be reached by a direct course over the ice without continuous land along which to travel. Having such willing and determined leaders as Commander Markham and Lieut. Parr, and the pick of the ship's company, who themselves were all chosen men out of numbers at hand, I sent them forth with full confidence that whatever was possible they would perform.

In organising this party, nothing was known of the movements of the Polar ice. I was even in doubt whether it was not always in motion in the offing, consequently I decided that boats must be carried of sufficient capacity for navigation, and not merely for ferrying purposes. This necessitated very heavy weights being dragged. It was also necessary that the party should carry a heavy load of provisions, for, owing to our clear weather and lofty look-out station, we had previously ascertained that no land existed within a distance of fifry miles of Cape Joseph Henry.

When a sledge party have to drag a boat even with only a few days' provisions, and over a smooth floe, double trips are necessary over the same road daily, in the same manner as Sir Edward Parry was compelled to journey in 1827 , consequently, the utmost limit that could be transported in this way with two trips on level ice was chosen, and this provided the party for an absence from the land for sixty-three days. The plan usually resorted to of reducing the weights carried by the advance party by providing a chain of supporting sledges is not applicable when each assisting sledge requires a boat capable of carrying its crew.

On the day following the departure of our traveling parties, Mr. Egerton and Lieut. Rawson returned from the Discovery after a rough journey, with a temperature ranging between $44^{\circ}$ and $15^{\circ}$ below zero, but all in good health and spirits, and beyond sore noses and tips of fingers from frost-bites, were none the worse for their cold journey.

The news from the Discovery was most cheering with the exception that, although they had succeeded in obtaining upwards of thirty musk-oxen, one man was in the sick list with a bad attack of scurvy. With this exception the crew of the Discovery had passed a very comfortable winter, plenty of cheerful work leading to and inducing constant employment of mind and body, coupled with a fair share of mirthful relaxation and a frequent meal of fresh meat. I refer you, Sir, to Capt. Stephenson's full report for a detail of his proceedings. His crew were preparing for the exploration of Lady Franklin Sound and the coast of Greenland.

On April 8 the first supporting sledge returned from Commander Markham's and Lieut. Aldrich's parties. As usual on the first starting several of the travellers were much distressed by the severe and unaccustomed work, and the cold weather preventing sleep at night, but were gradually improving. One man who had been ailing slightly during the last month was sent back, and one of the crew of the supporting sledge returned with a frostbite, the only serious case during the season, although the travellers, on two days out of the six that this party were away, experienced a temperature of $-46^{\circ}$.

On April to Lieut. Wyatt Rawson and Sub-Lieut. George Le Clere Egerton, having somewhat recovered after their cold journey to the Discovery, equipped with light sledres, started to ascertain the nature of the ice in
Robeson Channel, and to mark a convenient road across it for the heavier exploring sledges coming north from the Discovery under the command of Lieut. Lewis $A$. Beaumont.

On April 24 the second division of the supporting sledges returned, reporting the main parties to have settled steadily down to their work, and with the exception of one marine suffering from debility who was sent back, all were in good health and capital spirits. The temperature had fortunately risen to about -26 degrees. The very cold weather had tried the party much, and there had been numerous light cases of frost-bites, which but for the presence and care of Dr. Moss might have proved serious. The appearance of the ice within six miles of the land was anything but cheering to the northern party, but they looked forward with hope that the floes would get larger and less broken up as they advanced. Each sleoge carried extra tea in lieu of the usual midday allowance of spirits. Both men and officers were unanimous in favour of the change, and willingly put up with the misery of standing still in the cold with cold feet during the long halt needed for the purpose of boiling the water, and all agreed that they worked better after the tea lunch than during the forenoon.

On the I6th Lieut. Lewis A. Beaumont and Dr. Richard W. Coppinger arrived from the Discovery, having been ten days performing a travelling distance of seventy-six miles with light sledges, so broken up and difficult was the nature of the ice in Robeson Channel. They brought news that the ice was continuous and afforded fair travelling across Hall's Basin, and that the depôt of provisions at Polaris Bay was in good condition and fit for use. These circumstances enabled me to arrange for Lieut. Beaumont to proceed with lightly laden sledges along the Greenland coast to the eastward, and after completing his journey to fall back on the Polaris depôt before June 15 , by which time two boats would be carried across the straits from the Discovery, ready for his retreat should the ice have broken up.

On the 18th Lieut. Rawson and Mr. Egerton returned, having sicceeded in crossing the channel without finding more than the usual difficulties amongsi the heavy hummocks, which they had now become so accustomed to. They had landed on the Greenland coast north of the position marked as Repulse Harbour, which proves to be only a slight indentation in the coast line, baving a freshwater lake inshore $c f$ it, which from an inland view might readily be mistaken for a harbour.

On April 20 Lieut. Beaumont, accompanied by Lieut. Rawson and Dr. Coppinger, started for his Greenland exploration, the few days' rest having materially benefited his men, who may be said to have started from the Dis. covery unexperienced in Arctic sledging, that ship having had no autumn travelling in consequence of the ice remaining in motion until a very late period of the season.

On April 23 Capt. Stephenson and Mr. Thomas Mitchell, assistant-paymaster in charge, arrived from the Discovery, and I had the advantage of consulting with the former unreservedly concerning the prospects of our numerous travellers then scaitert over the neighbouring shores, the two ships remaining tenanted only by officers and a few invalids. Arrangements were made for the exploration of Petermann's Fiord, and should the season prove favourable, for the examination of the ice-cap south of Bessels Bay. On April 30 Capt. Stephenson returned to the Discovery.

Until the latter end of May sledge parties were continually arriving or departıng, carrying forward depôts of provisions for the use of the distant parties on their return. In carrying out these duties I was much indebted to Dr. Edward L. Moss, who again volunteered to command a sleoge, and I the more readily availed myself of his services knowing that it would afford him a wider field for continuing his scientific studies. Mr. James Wootton, 
engineer, also assisted me materially as commander of a sledge party.

On May 3 Lieut. Giffard returned with news from Lieut. Pelham Aldrich up to April 25, his twenty-second day out from the ship. He reported that all his crew were well and cheerful, but that the soft snow was causing very heavy and slow travelling.

Up to this time all had gone well with the expedition. The two ships had advanced as far north as was possible; they were admirably placed for exploration and other purposes ; and the sledge crews, formed of men in full health and strength, had obtained a fair start on their journeys under as favourable circumstances as possible. On May 3 Dr. Thomas Colan reported that five men had scorbutic symptoms; however, as each case had some predisposing cause, I was not alarmed until on the 8th the three ice quartermasters and two able seamen returning from sledge service were attacked, and by June 8 fourteen of the crew of the Alert and three men belonging to the Discovery who happened to be on board, forming the majority of the number of men then present, had been or were under the doctor's care for the same wasting disorder. Capt. Stephenson also reported that four more of his crew had been attacked.

Although many of the sledge crews formerly employed on Arctic research had been attacked by this disease some had totally escaped; therefore, considering the ample equipment and carefully prepared provisions with which the Alert and Discovery were provided, its outbreak was most inexplicable and unlooked-for. It was, however, most encouraging to learn from the report of former expeditions how transient the attacks had usually proved, and how readily the patients recovered with rest, the advance of summer, and a change to a more generous diet.

On May 9, by the return of Lieut. May and Mr. Egerton from Greenland, whither they had carried supplies and succeeded in discovering a practicable overland route immediately east of Cape Brevort fit for the use of the returning sledges should the ice break up, I received news of Lieut. Beaumont's party up to May 4, when he was within two miles of Cape Stanton. From their place of crossing the Straits they found that the coast line for nearly the entire distance to Cape Stanton was formed either by precipitous cliffs or very steep snow slopes, the bases of which receive the direct and unchecked pressure of the northern pack as it drifts from the north-westward and strikes against that part of the coast nearly at right angles. The floe-bergs, at their maximum sizes, were pressed high up one over the other against the steep shore; the chaos outside was something indescribable, and the travelling the worst that can possibly be imagined, seven days being occupied in moving forward only twenty miles. Being quite uncertain when such a road might become impassable by the ice breaking up in May as it did in 1872 , a depot of provisions, sufficient for a return journey by land, was wisely left, but Lieut. Beaumont's journey was thus shortened considerably.

As nearly every south-westerly wind we experienced at Floeberg Beach changed its direction to north-west before it blew itself out, the coast of Greenland north of Cape Brevort must necessarily be a very wild one as regards ice-pressure, and a most uncertain coast for navigation. A vessel once caught in the pack-ice off that shore, if not crushed at once, runs a great risk of being carried by it to the eastward round the northern coast, as pointed out by Admiral Sir George Back, Kt., F.R.S.

During the first week in May the temperature rising to zero enabled me to remove the snow from over the skylights and bull's-eyes and let in light between decks, but owing to there being no skylight over the lower deck it still remained very dark. I would here remark, Sir, how very important it is that Arctic ships should, if possible, be fitted with a large skylight above the ship's company's living deck.
On May 24 Lieut. Giffard returned on board, after depositing Lieut. Pelham Aldrich's last depôt of provisions, he and his crew having performed their inportant work well and expeditiously; but I am sorry to add that he brought Dr. Colan two more invalids. The attack occurring on his outward journey, as it was of vital importance that he pushed on, Lieut. Giffard was necessarily obliged to leave them in a snow hut for five days, one man taking care of the other as best he could until the party returned. Lieut. Giffard acted with great judgment, decision, and consideration on this occasion, and the two invalids recovered before the ship broke out of winter quarters.

On June I Mr. Crawford Conybeare arrived with news from the Discovery up to May 22. Lieut. Archer had completed his examination of the opening in the land west of Lady Franklin Sound, proving it to be a deep fiord terminating in mountainous land, with glaciercovered valleys in the interior.

Lieut. Reginald B. Fulford, with the men returned from Lieut. Archer's party, then transported two boats across Hall's Basin to assist Lieut. Beaumont in his return later in the season. Capt. Stephenson, accompanied by Mr. Henry C. Hart, naturalist, overtook this party on the 12 th at Polaris Bay. On the following day, the American flag being hoisted, a brass tablet prepared in England was erected at the foot of Capt. Hall's grave with due solemnity. It bore the following inscription :-

"Sacred to the Memory of Captain C. F. Hall, of the U.S. Ship Polaris, who sacrificed his Life in the advancement of Science, on the 8 th November, 1871 .

"This Tablet has been erected by the British Polar Expedition of 1875 , who, following in his footsteps, have profited by his experience."

Dr. Coppinger, when returning from assisting Lieutenant Beaumont, had visited Capt. Hall's Cairn at Cape Brevort, and the boat depôt in Newman's Bay, and conveyed the few articles of any value to the Discovery. The boat itself, with the exception of one hole easily repairable, was in a serviceable condition. Capt. Stephenson returned to the Discovery on May 18 , leaving Lieut. Fulford and Dr. Coppinger on the Greenland shore to explore Petermann Fiord. Mr. Crawford Conybeare having reported that the travelling along shore in Robeson Channel was fast becoming impracticable in consequence of the ice being in motion near the shore, his party were kept on board the Alert.

On the evening of June 8, Lieut. A. A. C. Parr arrived on board, most unexpectedly, with the distressing intelligence that nearly the whole of the crew belonging to the northern division of sledges were attacked with scurvy, and in want of immediate assistance. Commander Markham, and the few men who were able to keep on their feet, had succeeded in conveying the invalids to the neighbourhood of Cape Joseph Henry, thirty miles distant from the ship, but each day was rapidly adding to the intensity of the disease, and, while lessening the powers of those still able to work, adding to the number of the sick, and consequently, alarmingly increasing the weight which had to be dragged on the sledges. Under these circumstances, Lieut. Parr, with his usual brave determination, and knowing exactly his own powers, nobly volunteered to bring me the news, and so obtain relief for his companions. Starting with only an alpenstock, and a small allowance of provisions, he completed his long solitary walk, over a very rough icy road, deeply covered with newly fallen snow, within twenty-four hours.

Arrangements were immediately made to proceed to 
Commander Markham's assistance ; and with the help of the officers, who at once all volunteered to drag the sledges, I was able by midnight to proceed with two strong parties, Messrs. Egerton, Conybeare, Wootton, and White, the officers who could be best spared from the ship, taking their places at the drag ropes, Lieut. W. H. May and Dr. E. Moss pushing on ahead with the dogsledge laden with appropriate medical stores.

By making a forced march the two latter, with James Self, A.B., reached Commander Markham's camp within fifty hours of the departure of Lieut. Parr, although they were, I deeply regret to state, unfortunately too late to save the life of George Porter, Gunner R.M.A., who only a few hours previously had expired and been buried in the floe. Their arrival had a most exhilarating effect on the stricken party, who were gallantly continuing their journey as best they could. Early on the following day the relief party joined them, when the hope and trust which had never deserted these determined men was quickened to the utmost, even the invalids losing the depression of spirits always induced by the insidious disease that had attacked them, and which in their case was much intensified by the recent loss of their comrade. Early on the morning of the 14th, owing to the skill and incessant attention of Dr. E. Moss and the assistance of the dog sledge conducted by Lieut. May and James Self, A.B., who, with a most praiseworthy disregard of their own rest, were constantly on the move, Commander Markham and $I$ had the satisfaction of reaching the ship without further loss of life; and after a general expression of thanksgiving to God for his watchful care over the lives of the survivors, of placing them under the skilful charge of Dr. T. Colan, Fleet-Surgeon.

Of the original seventeen members composing the party, only five - the two officers and three of the men, John Radmore, chief carpenter's mate, Thomas Joliffe, first-class petty officer, and William Maskell, A.B.-were able to drag the sledges alongside. Three others, Edward Laurence, captain forecastle, George Winston, A.B., and Daniel Harley, captain foretop, manfully kept on their feet to the last, submitting to extreme pain and fatigue rather than, by riding on the sledge, increase the weight their enfeebled companions had to drag, and were just able to walk on board the ship without assistance. The remaining eight, after a long struggle, had been forced to succumb to the disease, and were carried on the sledges. Out of the whole number, the two officers alone escaped the attack of scurvy. Atter a few days' rest and attention, John Radmore, chief carpenter's mate, returned to his duty, and three of the others were able to attend on their sick comrades : but Thomas Joliffe, who had most manfully resisted the disease while actively employed, when his legs became cramped from resting on his return on bcard, was one of the most lingering cases. These men gradually recovered, and were all out of the sick list before the ship was free of the ice during the passage home.

In journeying to the northward, the route, after leaving the coast, seldom lay over smooth ice; the somewhat level floes or fields, although standing at a mean height of 6 feet above the neighbouring ice, were small, usually less than a mile across. Their surfaces were thickly studded over with rounded blue-topped ice humps, of a mean height above the general level of from to to 20 feet, lying sometimes in ranges, but more frequently separated at a distance of from 100 to 200 yards apart, the depressions between being filled with snow deeply scored into ridges by the wind, the whole composition being well comparable to a suddenly trozen oceanic sea. Separating these floes, as it were, by a broadened-out hedge, lay a vast collection of débris of the previous summers, broken up pack-ice, which had been re-frozen during the winter into one chaotic rugged mass of angular blocks of various heights up to 40 and 50 feet, and every possible shape, leaving little, if any, choice of a road over, through, or round about them. Among these was a continuous series of steep-sided snow drifts sloping down from the highest altitude of the pressed-up ice until lost in the general level at a distance of about roo yards. The prevailing wind during the previous winter having been from the westward, and the sledges' course being due north, these "sastrugi," instead of rendering the road smoother, as they frequently do in travelling along a coast line, when advantage can be taken of their long smooth tops, had to be encountered nearly at right angles. The whole formed the roughest line of way imaginable, without the slightest prospect of ever improving. The journey was consequently an incessant battle to overcome ever recurring obstacles, each hard-won success stimulating them for the next struggle. A passage had always to be cut through the squeezed-up ice with pickaxes, an extra one being carried for the purpose, and an incline picked out of the perpendicular side of the high floes or roadway built up, before the sledges, generally one at a time, could be brought on. Instead of advancing with a steady walk, the usual means of progression, more than half of each day, was expended by the whole party facing the sledge and pulling it forward a few feet at a time. Under these circumstances, the distance attained, short as it may be considered by some, was truly marvellous.

The excellent conduct of the crews and the spirit displayed by them, combined with the work performed, indicated in a striking manner the sense of confidence in the leaders which they enjoyed, and points unmistakably to the watchful care taken of themselves and to the general good guidance of the party.

No two officers could have conducted this arduous journey with greater ability or courage than Commander Albert H. Markham and his very able second in command, Lieut. A. C. Chase Parr, and I trust that their Lordships will notice their services by some mark of approval. The services of Thomas Rawlings and Edward Laurence, Ist class petty" officers, filling the highly important positions of captains of the sledges, was beyond all praise. In addition to their general cheerfulness and good humour, to their care and skill must be attributed the safe return of the sledges, on which the lives of the party depended, uninjured, and in as serviceable a state as when they left the ship, notwithstanding the heavy nature of the road, which on all former ocrasions not only repulsed the travellers altogether, but drove them back with broken-up equipment. To such men as these, and the sledge crews generally, it is difficult to find any reward which can in the least compensate them for the manner in which they have manfully met the extreme privations and continuous labour necessarily undergone. During this memorable journey to penetrate towards the north over the heavy Polar oceanic ice, without the assistance of continuous land along which to travel, in which has been displayed in its highest state the pluck and courageous determination of the British seaman to steadily persevere, day after day, against apparently insurmountable difficulties, their spirits rising as the oppositions increased, Commander Markham and Lieut. Parr and their brave associates succeeded in advancing the National Flag to lat. $83^{\circ} 20^{\prime} 26^{\prime \prime} \mathrm{N}$., leaving a distance of 400 miles still to be travelled over before the North Pole is reached.

In order to attain this position, although a direct distance of only seventy-three miles from the ship was accomplished, the total distance travelled was 276 miles on the outward, and 245 miles on the homeward journey. Their severe labour and exertions which certainly can never be surpassed, coupled with the experience gained by Sir Edward Parry in the summer of 1827 , proves that a lengtheried journey over the Polar pack ice with a sledge party provided with a navigable boat is, in consequence of the rough nature of the road over which the party has to travel, impracticable at any season of the year; and 
further, as the sledges were necessarily advanced each stage singly, we are enabled to estimate the exact rate of progression which may be expected should anyone consider it desirable to push forward with light sledges withcut any additional means of returning later in the season in the event of the ice breaking up in his rear. The maximum rate of advance in this way was at the rate of $2 \frac{3}{4}$ miles a day, the mean being at the rate of $1 \frac{1}{4}$ miles a day.

It may be necessary here to state that the much to be deplored outbreak of scurvy, which certainly shortened the journey to the extent of some ten or twenty miles, in no way affects the conclusions to be derived from it. When the first two men who were attacked complained of sore legs, the disorder so commonly experienced by travellers in all countries, and particularly those employed to drag Arctic sledges, the loss of their services at the drag ropes was fully balanced by one of the two boats being left behind, thus, the daily distance accomplished during the first twenty-five days of the outward journey was not materially altered, and it was only during the latter fourteen davs, that owing to the gradual breakdown of three more of the crew, the rate of advance was necessarily much retarded. The previous rate, however, had been so slow that the party gallantly continued their advance to the utmost limit of their provisions, confident that with the help of the manual labour of the officers, who from the first took their places at the drag ropes and pickaxes and worked as bard as the men, they could readily return to the land along the road on which they had expended so much labour in somewhat levelling during their outward journey.

'The scurvy by this time having with very few exceptions, attacked the whole ship's company, I was somewhat anxious concerning the health of Lieut. Aldrich's men returnirg from their western journey; particularly when I observed that the cairn erected over his depôt of provisions, thirty miles to the north-west, remained untouched on the day appointed for his arrival there ; accordingly I sent Lieut. May with the dog sledge, and three strong men to meet him. On June 20 the two parties joined company at the depôt and signalled their arrival to the ship. Lieut. Aldrich had crossed the land only just in time, for on the following day a gale of wind from the southward commenced bringing warmer weather, and the thaw set in with such rapidity that the snow valleys on the land were rendered impassable for sledges for the remainder of the season. Lient. May met the party on the very last day, when most of them were able to travel, baving succeeded in reaching, after a very severe journey most courageously borne, the same position to which Commander Markham's party had returned without assistance; but there the same blight that attacked the northern party, and against which the western division had long been struggling, gained on them so quickly that, with the exception of Lieut. Aldrich and Adam Ayles (P. O., 2nd class), the whole crew were placed hors de combat, James Doidge (Ist class P.O.) and David Mitchell (A.B.) still gallantly struggling along by the side of the sledge, the other four invalids, having beld out until the last moment, were obliged to be carried. Under these circumstances the arrival of Lieut. May with relief was most providential. With their assistance Lieut. Aldrich succeeded in reaching the Alert on the morning of the $26 \mathrm{th}$, when, after again publicly returning thanks to Almighty God for his watchful care over the lives of the party, they were placed under Dr. Colan's charge, the officer being the only one not attacked by scurvy.

Notwithstanding a bad start, owing to the necessity of crossing the land with heavily laden sledges, Lieut. Aldrich with great energy succeeded in exploring the coast line to the westward for a distance of 220 miles from the position of the Alert. Trending first to the north-westward for ninety miles to Cape Columbia, the extreme northern cape in lat. $83^{\circ} 7^{\prime} \mathrm{N}$, and long. $70^{\circ} 30^{\prime}$ W., the coast extends to the west for sixty miles to long. $79^{\circ} \mathrm{o}^{\prime} \mathrm{W}$. and then gradually trends round to the southward to lat. $82^{\circ}$ I $6^{\prime} \mathrm{N}$. and long. $85^{\circ} 33^{\prime} \mathrm{W}$., the extreme position attained. No land or appearance of land was seen at any time to the northward or westward, and owing to the continued heavy nature of the ice. I conclude that no land can possibly exist within an attainable distance from this coast. Although most of the party suffered more or less duting the outward journey, the attack was supposed to be merely transient, and it was not until they were returning home when the scorbutic symptoms of sore gums first made their appearance, that the real nature of the disease was in the least suspected. To these men equal praise is due as to their comrades employed in the northern division for the endurance and intrepidity with which each individual performed his respective duty. Crippled nearly as badly, they if possible suffered more severely; for being so distant from relief none could be carried without imperilling all, and each was obliged to remain toiling at the drag ropes making forced marches.

It is to Lieut. Aldrich's judicious care and energy during the long and anxious homeward march, seconded by the spirited example of Joseph Good, acting chief boatswain's mate, captain of the sledge, himself one of the most enfeebled of the party, that they owe their lives. Lieut. Aldrich's services on this, as on all other occasions during the three years he has been under my command, calls for my unqualified admiration; he is a talented and zealous officer, and in every way deserving of their Lordships' consideration.

Again, Sir, I have to bring to your notice the valuable services of Lieut. May and James Self, A.B.; the thaw having set in, it was principally due to their incessant labour that the party arrived on board before the rapidly advancing disease had further developed itself.

With regard to the outbreak of scurvy, which attacked the crew of the Discovery as well as ourselves, when the sledge crews started early in Apri], a finer body of men in apparently perfect health it would have been difficult to pick anywhere, and I trusted that, owing to the excellent condition of our provisions, we were secure from any attack, but I must now conclude that disease was even then lurking among us, and that the heavy labour of sledge travelling intensified and brought it out, as has been the case in nearly all former journeys when the travellers have been unable to procure large supplies of game, and were unprovided with lime juice. It attacked first the weakly men, afterwards the strong men who were predisposed for it, and most severely of all those who were employed on the longest and most trying journeys. Had there been no sledging work I believe that the disease would not have betrayed its presence amongst us, and had the officers been called upon from the first to perform as severe daily labour as their men I think that they would have been equally attacked.

On July 9, fifteen days after the return of the last sledge party, thirty-six of the crew of the ship had been, and twenty-four were, under treatment for scurvy. This large number of patients, most of them requiring constant and special attention, necessarily taxed to the utmost the services of Dr. Thomas Colan, Fleet Surgeon, and his able second, Dr. Ed. Moss, Surgeon. Nothing could exceed their indefatigable patience and care. The deprivation of necessary rest and exercise cheerfully submitted to by Dr. Colan, upon whom the chief responsibility fell, considerably impaired his own health, following as it did so closely on his long anxious watch by the bedside of Neil Petersen.

In order to preserve the continuity of the narrative, I will here report the result of Lieut. Beaumont's exploration on the Greenland coast, but which I only learnt some time afterwards. 
On August 6, while the Alert was imprisoned by the ice twenty miles north of Discovery Harbour, during her passage down Robeson Channel, Lieut. Rawson and two men arrived with letters from Capt. Stephenson containing the distressing intelligence that scurvy had attacked the Greenland Division of sledges with as much severity as it had visited the travellers from the Alert, and that Licut. Beaumont was then at Polaris Bay recruiting his men. I must refer you, Sir, to Capt. Stephenson's letters and to Lieut. Lewis A. Beaumont's report for a full detail of the proceeding of this party, but I may here mention the chief points. I have already reported their movements up to May 5, when Dr. Coppinger" left them; Lieut. Beaumont with two sledge crews journeying to the riorth-eastward along the north coast of Greenland, all apparently in good health. A very few days after, James J. Hand, A.B., who had passed the winter on board of the Alert, showed symptoms of scurvy. As soon as the nature of the disease was decided, Lieut. Beaumont determined to send Lieut. Rawson with three men and the invalid back to Polaris Bay, and to continue the exploration with reduced numbers. Lieut. Wyatt Rawson parted company on his return on May II ; but owing to two more of his crew breaking down, leaving only himself and one man strong enough to drag the sledge on which lay the principal sufferer, and to look after the other two, he only succeeded in reaching the depot on June 3 , James J. Hand unhappily dying from the extreme fatigue a few hours after the arrival of the party at Polaris Bay. Out of the other men forming the sledge crew, who had all passed the winter on board the Alert, only one of them--Elijah Rayner, Gunner, R.M.A.--escaped the insidious disease; George Bryant, Ist class petty officer and captain of the sledge, and Michael Regan, A.B., were both attacked, the former, although in a very bad state, manfully refused to the last to be carried on the sledge, knowing that his extra weight wou'd endanger the lives of all.

I cannot praise Jieut. Rawson's conduct on this occasion too highly; it is entirely due to his genial but firm command of his party, inspiriting as he did his crippled band, who relied with the utmost confidence on him, that they succeeded in reaching the depôt. His return being totally unexpected, no relief was thought of, nor, indeed, were there any men to send. On June 7 Lieut. Fulford and Dr. Coppinger, with Hans and the dog-sledge, returned to Polaris Bay depôt from the exploration of Petermann Fiord; and, with the help of some fresh seal meat and the professional skill and care of Dr. Coppinger, the malady was checked and the sick men gradually regained strength.

Lieut. Beaumont, continuing his journey on May 2r, succeeded in reaching lat. $82^{\circ} \mathrm{I} 8^{\prime} \mathrm{N}$., long. $50^{\circ} 40^{\prime} \mathrm{W}$., discovered land, apparently an island, but, owing to the nature of the ice, probably a continuation of the Greenland coast, extending to lat. $82^{\circ} 54^{\prime} \mathrm{N}$., long. $48^{\circ} 33^{\prime} \mathrm{W}$. By this time two more of the crew showed symptoms of scurvy, and soon after the return journey was commenced the whole party were attacked, until at last Lieut. Beaumont, Alexander Gray, sergeant-quartermaster captain of the sledge, and Frank Jones, stoker, were alone able to drag, the other four men having to be carried forward on the sledge in detachments, which necessitated always double and most frequently treble journeys over the rough and disheartening icy road; nevertheless, the gallant band struggled manfully onwards, thankful if they made one mile a day, but never losing heart; but Lieut. Beaumont's anxiety being intense lest relief should arrive too late to save the lives of the worst cases. Not arriving at Polaris Bay on the day expected, Lieut. Wyatt Rawson and Dr. Richard W. Coppinger, with Hans and the dog-sledge, started on June 22 to look for them, the two parties providentially meeting in Newman's Bay, twenty miles from the depôt. The following day Frank Jones being unable to drag any longer, walked; leaving the three officers and Alexander Gray to drag the four invalids, the dogs carrying on the provisions and equipage. On the $27^{\text {th }}$ Alexander Gray was obliged to give in, and the officers had to drag the sledge by themselves, Gray and Jones hobbling along as best they could. On the 28 th, being within a day's march of the depôt with the dogs, the two worst cases were sent on in charge of Dr. Coppinger, and arrived at the end of the march, but I regret to state that Charles W. Paul, A. B., who joined the expedition from the Valorous at Disco, at the last moment, died shortly after their arrival. The remainder of the party, helped by Hans and the dogs, arrived at the depôt on Juiy r, and it being impossible to cross the strait and return to the Discovery before the invalids were recruited, at once settled themselves down for a month's stay, those able to get about shooting game for the sufferers with such success that they obtained a daily ration of fresh meat. It was entirely due, under Providence, to the timely assistance dispatched by Lieut. Rawson, who, as senior officer at Polaris Bay, when there was not time to cross Hall's Basin and inform Capt. Stephenson of his apprehensions, acted promptly on his own authority and went to the relief of Licut. Beaumont's party, that more casualties did not occur.

After such details it is scarcely necessary for me to allude to the services of Lieut. Beaumont. The command of the Greenland sledges, entailing as it did the crossing and recrossing of Robeson Channel-which in 1872 remained in motion all the season-required even greater care and judgment than is always necessary in the leader of an Arctic sledge party. My confidence in Lieut. Beaumont, as expressed in my original orders to him, was fully borne out by his careful conduct of the party throughout this trying and most harassing march. He is a most judicious, determined, and intelligent leader, and as such I bring his services to the notice of their Lordships.

Capt. Stephenson by personal inspection having satisfied himself tirat the resources of the Polaris depôt wera sufficient and apgropriate for the subsistence of the men detached to the Greenland shore, although naturally anxious at their non-arrival on board the Discovery, was not alarmed for their safety. On July 12 Lieut. Fulford, with two men and the dog-sledge, were dispatched across Hall's Basin to Discovery Bay, and arrived there on the third day, having found the ice in motion on the west side of the channel, and experiencing much difficulty in effecting a landing. On the receipt of the news Capt. Stephenson instantly started with a relief party, carrying medical comforts, and arrived at Polaris Bay on the Igth. On the following day the ice was in motion on both sides of the channel. On the 29th Capt. Stephenson, with Lieut. Rawson, Hans, and four able men, with two invalids who could walk, started with the dingy for Discovery Bay, and after a very wet journey they landed on the west shore on August 2, Lieut. Beaumont and Dr. Coppinger, with five strong men, being left for a few days longer in order to give the other two invalids further time to recruit. The whole party ultimately re-crossed the Strait, and arrived at Discovery Bay on August r4, having been absent from their ship I 20 days, several of the party who had wintered on board of the Alert having been absent since August 26 the previous year.

Great praise is due to Dr. Richard W. Coppinger for his skilful treatment of tbe disease; living as he and the party did for from six to eight weeks in tents on an Arctic shore without extra resources or medicines, except at the last, it is much to his credit that on their arrival on board the Discovery all the patients were able to perform their ship duties. All speak in the highest terms of Hans the Esquimaux, who was untiring in his exertions with the dog-sledge, and in procuring game-it was owing to his patient skill in shooting seal that Dr. Coppinger was able to regulate the diet somewhat to his satistaction. Lieut. Reginald B. Fulford, and Dr. Richard W. Cop- 
pinger cleared up all doubt about the nature of Petermann Fiord, having reached at a distance of nineteen miles from the entrance, the precipitous cliff of a glacier which stretched across the Fiord.

Oil considering the result of the spring sledging operations, I concluded that, owing to the absence of land trending to the northward and the Polar pack not being navigable, no ship could be carried north on either side of Smith's Sound beyond the position we had already attained; and also that from any maintainable position in Smith's Sound it was impossible to advance nearer the pole by sledges. The only object, therefore, to be gained by the Expedition remaining in the vicinity for another season, would be to extend the exploration of the shores of Grant Land to the south-westward, and Greenland to the north-east or eastward, but as with the whole resources of the expedition I could not hope to advance more than about fifty miles beyond the positions already attained on those coasts, and moreover, although the crew were ripidly recovering from the disease which had attacked them, they would certainly be unfit for employment on extended sledge parties next year, I decided that the Expedition should return to England as soon as the ice broke up and released the ship. It was with the very sreatest regret $I$ felt it my duty to give up the very interesting further examination of the northern coast of Greenland.

Although pools of water formed along the tidal crack in the ice early in June, the thaw did not regularly set in before the last week of the month. On July $I$ water in the ravines commenced to run, after that date the thaw was very rapid both on shore and on the ice, but no decided motion took place before the 2oth. On the $23 \mathrm{rd}$, with a strong south-west wind, the pack was driven a mile away from the shore, but, as in the autumn, no navigable channel made to seaward or along the land to the westward of Cape Sheridan. On the 26 th a record was left in a cairn erected on shore detailing the work performed by the expedition, and of my intention to proceed to the scuthward. On the 3Ist, after considerable labour to clear away a passage through the barrier of floe-bergs which had so well protected us during the winter, we succeeded during a strong south west wind, which drove the pack out to sea, in rounding Cape Rawson and entering Robeson Channel on our return voyage. After a ten miles run along shore, through a fairly open channel between the pack and the cliffy ice foot bordering the coast, we were stopped by a heavy floe one-and-a-half miles in diameter nipping against the land four miles north of Cape Union, and there being no other protection attainable, the ship was secured in a small indentation among a group of grounded floe-bergs lining the shore off a shallow part of the coast. The ice in the offing drifced north and south with the tides in a nearly compact mass, that near the shore alone being loose, but in no way navigable.

Early in the morning of August I, the heavy floe which had stopped us the previous day commenced to move, and was soon travelling to the northward with the whole strength of the tide at the rate of one-and-a-half miles an hour, scraping along the ice foot as it advanced towards the ship in a rather alarming manner. Steam being fortunately ready we cast off, and succeeded in passing between it and the shore, as after a severe wrench against a projecting point close ahead of us, a channel was opened by its rebound, as it coach-wheeled round the north point of the floe, lurned in towards the land close to the position which we had vacated a few moments before.

The difference between an ordinary floe and Polar Sea ice was here exemplified completely; the former composed of ice about 6 feet in thickness, on meeting with an obstruction is torn in pieces as it presses past it; the latter being some 80 or roo feet thick, quietly lifts any impediment away ou: of its course, and takes no further notice of it. Such was the case on this occcasion: the Polar floe, which we only escaped by a few yards, on nipping against the heavy breastwork of isolated floe-bergs lining the coast, some of them 40 feet high and many thousand tons in weight, which had lately formed our protection from the smaller ice pieces, tilted them over one after another, and forced them higher up the landslope, like a giant at play, without receiving the slightest harm itself, not a piece breaking away. It was most pro. vidential, that by its twisting round the Alert was enabled to escape out of the trap in which she was inclosed.

Steering onward, so close to the shore ice-cliff-from 20 to 40 feet high, and having ten to twenty fathoms water alongside it - that the quarter-boats touched on several occasions, we reached within two miles of Cape Union, but in consequence of the pack remaining close in the cape, both during the flood and ebb tides, the ship was again brought to a stop. Fortunately we were able to secure her abreast of a large water-course, the stream of which had been powerful enough to undermine the icecliff to such an extent as to allow fifty yards of it to break away and float off to sea; this left just sufficient space in which to secure the ship alongside the beach in such a manner that in the event of a nip taking place she would merely be forced on the shore before the floe itself grounded. Here we were delayed for twenty-four hours with the boats from the exposed side lowered down and moored in-shore for safety.

At half flood, the south-running tide, a narrow lead of water formed round the cape ; steam was got up immediately, but owing to delay in shipping the rudder consequent on the tide running towards the bow carrying it under the ship's bottom, the ice closed in again before I could get round; it also cut us off from our friendly little haven, and I was therefore obliged to secure the ship during the north-running tide in a slight indentation in the high cliffy ice-foot. Fortunately being within half-a-mile of Cape Union, the run of the ice, as it passed to the northward round the Cape, kept at about twenty yards from the land until after it had passed our position; only the lighter ice pieces scraping their way along the ship's side.

As we would be exposed to the whole pressure of the ice during the south-going tide, at 4 P.M., low water, it being calm and no prospect of a westerly wind to open a navigable passage, I cast off and bored a short distance into the pack with the purpose of allowing the ship to drift round the Cape with the flood or south-going tide. The ice carried her with it about a quarter of a mile distant from the land, with no navigable water in sight, the whole pack moving steadily together without nipping to any great extent. As we passed we noticed that the front of the ice-foot was perfectly smooth, and would afford no protection whatever if we were obliged to leave the pack. As the tide slackened we succeeded with great trouble in steaming out of the pack just as the ice commenced to set to the northward with great rapidity. As it remained slack for some twenty yards from the beach, we were able to proceed slowly to the southward, close to the ice-foot; the midship boats being turned in-board, but the quarter-boats which could not be protected, being in constant peril of a squeeze. The water channe! widened considerably as we approached Lincoln Bay, and we crossed it without any trouble, and arrived within five miles of Cape Beechey before the tide turned, to run south again, when $I$ secured the ship alongside a heavy polar floe-piece, with the kope of again drifting south; but finding that the lighter pieces of ice were drifting faster and gradually inclosing us, I was obliged to cast off, and with much trouble succeeded in reaching the north side of Cape Beechey, before the north running tide made at noon, August 3. After two hours waiting, there being plenty of water space to the northward, a channel opened and allowed us to get round the Cape. Here the cliffy ice-foot comes to an end with the precipi- 
tous land. South of the Cape the land slopes down to the shore line, and is fronted by a breast-work of broken off floe-bergs similar, but somewhat smaller, than those lining the shore of the Polar Sea ; among these the ship was secured in three fathoms water within twenty yards of the shore, a mile south of the Cape, and considering our much more exposed position during the winter, I thought the ship secure.

During August 4 the weather was overcast with snow squalls from the south-west, with a low barometer but not much wind. As the ice had closed in and locked the ship up completely, the sportsmen visited the lakes where three musk-oxen had been shot the previous surnmer. A number of geese were found all unable to fly ; the old ones moulting were nearly featherless, and the young ones not yet having grown theirs; consequently fifty-seven were captured, a very welcome supply for the invalids, of whom we had ten still remaining. The ice remaining close, and being only twenty miles from the Discovery, Mr. Egerton, with a seaman for a companion, was sent to her on August 5 with orders for her to prepare for sea. They had a rough and troublesome walk over the hills, but arrived the same evening.

During our detention in this position, the pack in the offing drifted up and down the strait with the tide, the wind having the effect of increasing the speed of the current, and the duration of its flow both towards the north and the south. Although the ice generally was of a considerably lighter character than that in the Polar Sea, or at the northern entrance of Robeson Channel, a number of heavy Polar floes passed us, driven to the southward by the northerly wind, and set into Lady Franklin Sound and Archer Fiord rather than down Kennedy Channel. In fact, that Sound may be considered as a pocket receiving all the heavy ice driven south through Robeson Channel, and retaining it until the prevailing westerly winds carry it to to the northward again, and clear out the Sound ready to be re-filled when the north wind returns. It is only during seasons when northerly winds prevail considerably over the westerly ones, that the heavy Polar ice is carried south in large quantities into Smith's Sound and Baffin's Bay.

On August 6 the wind increaced considerably from the north until it blew a gale. During the height of the flood or south-going tide a succession of heavy floe piece's passed us drifting down the strait, toying with our barrier of outlying protections, and turning one large one completely topsy-turvy. It was firmly aground in twelve fathoms water on an off-lying shoal some 200 yards from the main line of the floe-bergs, and on this and the previous days had been of great service in keeping the line of the drifting pack at a safe distance from us; but on this occasion the point of a large floe which was drifting south close in shore brought the weight of the whole pack on the doomed mass. As it received the pressure the floe-berg was reared up in the air to its full height of at least 60 feet above water, and turning a complete somersault, fell over on its back with a tremendous splash, breaking into a number of pieces with a great commotion and raising a wave sufficiently to roll the ship considerably. Our protecting floe-berg carried away, the ice moved in, forcing the ligbter floe-bergs one after the other, as they became exposed farther in-shore, and at last nipped the ship slightly. This evening Lieut. Rawson and two seamen arrived from the Discovery with news of the Greenland division of sledges. On the morning of August 7 , with the wind blowing slightly off the land, the ice eased off shore, and cleared the nip round the ship, but did not allow me to move to a more sheltered position. In the afternoon, a temporary opening occurring, steam was raised and the rudder shipped, but owing to some of the ropes fouling, the latter was not ready before the ice closed in and imprisoned us again. During the night the wind increased considerably, and with the south running tide the ice was being carried past us at the rate of two miles an hour. Owing to several heavy pieces grounding outside our line of barrier ice, the inner edge of the pack was guided more towards our position, and at last two heavy pieces wedged themselves against the ship, the inner one grounding alongside the ship after forcing her very close to the shore, and nipping her to such an extent that the ship was raised bodily 3 feet. As the tide rose the lighter ice in-shore gradually forced its way under the ship's bottom an 1 relieved the pressure somewhat ; so that after four hours she was only raised about 6 inches above her usual draught of water.

As there was now no hope of releasing the ship, except by cutting down the heavy piece of ice which was aground outside us, all hands were set to work with pickaxes to lighten it. On August Io, after three days' work, the ice having been sufficiently reduced, floated at the top of high water, and released the ship; the main pxck moving off shore at the same time, we advanced five miles, and on the following day, after much trouble, succeeded in joining company with the Discovery. Sending all my sick men to the Discovery, the Alert was secured at the entrance of the harbour ready to start for Polaris Bay to relieve Lieut. Beaumont immediately the ice permitted me to cros3; but his arrival on August 14, as before stated, fortunately rendered this passage unnecessary. The Discovery having embarked her coals and provisions, both ships were now realy to continue their voyage to the southward, but although water was observed in Kennedy Channel, the whole of Lady Franklin Sound remained filled with the ice brought to the southward by the late northerly gale. While waiting, ready to start, each of the ships tailed on shore at nearly low water, but floated again without damage.

We were delayed here with calm weather and consequent little motion in the ice until August 20, when, a chance offering, we pushed our way through the pack, which, gradually opening as we advanced, led us into comparatively open water off Cape Lieber, where a strong south-westerly wind had been blowing for several days but had not been able to force its way across the ice in Hall's Basin. As we neared Cape Lawrence, the ice, which had been getting closer as we advanced south, became so close that we must either return north, run into the pack, or secure the ships to some of the grounded floe-bergs or icebergs. I chose the latter, and ent ring the bay immediately south of the cape, we followed the coast until we found ourselves in a large inner basin perfectly land-locked, and I made the ship; fast with perfect confidence, although with the spring flood-tide the ice was floating sluggishly in and gradually filling up the bay. It happened, unfortunately, that at the very top of high-water a rather insignificant-looking prece of ice pressed against the ship, when the floe-berg in-shore of us, and against which the ship was resting, having floated with the spring tide, allowed itself to be pressed in-shore, and suddenly we found the ship aground forward with deep water under the stern. Before any means could be taken to release her from this position the tide had fallen I4 feet at low water, leaving the fore foot and keel bare as far aft as the fore channels, the ship lying over on her bilge at an angle of twenty-two degrees. As the tide rose, the ship was lightened, the cables hauled aft, and the anchors lowered on to suitable pieces of ice. One of these was then hauled astern to a proper position, when by blowing up the ice the anchor was laid out with great ease. At high water the ship was hauled off without having received any injury. On August 22 a southwest wind opened a passage again, of which immediate advantage was taken, and we proceeded to the southward as far as Cape Collinson with only the ordinary troubles in ice navigation, during thick snow-storms, misty weather, and strong head winds. Oif the cape, owing to the Alert being obliged to back astern to escape a nip, the two 
ships fouled for a few moments, and the Discovery lost a boat's davit, but by smart and skilful management saved the boat. I may here add that such has been the skill displayed by the officers of the watches of the Alert and Discovery, although the two ships have frequently been necessarily within touching distance of each other, and of the ice-cliffs and bergs, this is the only accident of consequence which occurred during the voyage. The ice closing in ahead, the two ships were made fast inside some grounded icebergs in Joiner Bay, one mile north of Cape McClintock.

In Rawlings Bay, south of Cape Lawrence, icebergs are found for the first time on coming from the northward. All to the northward may be considered as floe-bergs. Few even of the initiated can distinguish one from the other, so like are they; and certainly any stranger would be deceived, the floe-bergs being frequently larger than the icebergs. The ice-foot is also totally different, being formed by the pressure of lighter ice, it does not project into such deep water; consequently, whereas we could secure the ship alongside the ice-foot in Robeson Channel with confidence of her not grounding, in Kennedy Channel and all parts to the South of it there is only one fathom water alongside the icy cliff at low water.

Starting again in the evening, as an increasing southwest wind gradually opened the ice to the southward, we crossed Scoresby Bay, which, extending from fifteen to twenty miles in a south-west direction, was perfectly clear of ice, the fresh breeze blowing down it raising a sea which caused the ships to pitch slightly, and materially stopped their speed through the water. Approaching Cape Frazer, the wind was blowing a whole gale, and I was forced to expend much coal in reaching Maury Bay immediately nurth of it, and in which the two ships were anchored among a lot of grounded ice, but the squalls off the land rendered it anything but a safe or comfortable position. We were delayed three days rounding Cape Frazer and Cape Hayes, the turning point of the channel, and consequently a troublesome piece of navigation. On the $25^{\text {th }}$, aiter twice being driven back into Maury Bay, we succeeded in securing the ships inside some grounded icebergs near Cape Louis Napoleon, the same ir all probability that sheltered us when bound to the northward the previous spring.

Much has been said concerning the expected difficulty of passing Cape Frazer, on account of the two flood tides, one coming south from the Polar Sea, and the other north from the Atlantic, being supposed to meet there, and by so doing collect a quantity of ice in the neighbourhood. Were ice navigation dependent on tidal currents alone, then at the position of slack water, where there is a minimum ebb and flow, a vast quantity of ice might be collected by the two flood tides, but on the other hand there would be an equal chance of the two tides carrying it away in opposite directions ; however, as wind is of far greater importance than tidal movement, the case need not be considered. The two tides do meet at Cape Frazer, the actual position varying a few miles north or south according to the prevailing wind, and also the ice is certainly accumulated immediately about and south of the cape in great abundance. But this is owing to the ending of Kennedy Channel, and the strait widening considerably at that place into Smith's Sound proper. While many causes tend to keep narrow channels clear, enlarged seas with narrow outlets are naturally encumbered with ice.

I found no greater danger or trouble in passing Cape Frazer than in navigating elsewhere, except from what is caused by that cape being the turning point of the coast line, where no one wind blowing up or down the strait is able to clear away the ice on the north and south sides of the cape at the same time. Struggling slowly and patiently along, gaining about one mile a day by moving forward from the protection of one stranded iceberg to that of another, as slight movements in the ice during the calm weather allowed, and al hough obliged to enter the pack occasionally, always keeping as near the shore as prudent, we rounded Cape Louis Napoleon, and on the 29th arrived at Prince Imperial Island, in Dobbin Bay, everyone heartily thankful to be out of the pack, clear of the straggling icebergs, and for the ships to be secured to fixed ice once more.

During the previous week we had experienced much misty weather with a heavy fall of snow, measuring five inches, which changed the whole aspect of the land by reclothing the richly-tinted stratified mountains with their winter garb, from which they had only been free for a short seven weeks; afterwards the snow only melted slightly in the low-lying valleys. A northerly wind now set in, not strong enough to effect the movements of the ice materially, but sufficiently so to clear the atmosphere and lower the temperature considerably below freezing-point; after this date the young sea-ice formed continually day and night. As the mist cleared away it disclosed a fine panorama of lofty snow-clad mountains with glacier-filled valleys intervening; one large one extending to the shore discharges numerous icebergs into Dobbin Bay. This, the largest discharging glacier on the west shore of Smith Sound, was named after the Empress Eugenie, who, besides taking a personal interest in the expedition by her thoughtful present of a number of homely but most useful articles, added considerably to the comfort and amusement of each indiviaual.

On September I we crossed Dobbin Bay and succeeded in securing the ships to an iceberg aground only a quarter of a mile from the depôt of provisions left by us the previous spring a few miles north of Cape Hawkes, but such was the thickness of the newly-formed ice that boat work was nearly out of the question; by working in the cracks opened by the ebb tide some of the provisions were embarked, but there is still a boat and a large quantity of biscuit left on shore there. The same reason prevented my landing on Washington Irving Island and visiting our own cairn until the third day, when the spring tide having opened a water passage I found that our notice had $r_{2}$ ot been visited since we left it. The two old cairns erected by former travellers were again visited; the lichens which had spread from stone to stone proving that they are undoubtedly of very ancient date. They were probably erected to mark the farthest north point reached by one of our enterprising and gallant predecessors who never returned home.

On September 3 a lane of water opening along shore to the westward of Cape Hawks, every exertion was made to reach it, but owing to the newly made ice, which by cementing together a number of loose pieces of old ice formed a barrier between us and the water, we only succeeded, after long perseverance, in ramming our way through it at a large expenditure of coal. After rounding the Cape, the pack by drifting away from the land had left unfrozen water and numerous detached small floes which forced us to make a very serpentine course, and occasionally to pass within thirty yards of the low icefoot on the shore, fortunately always finding deep water. The outer pack, consisting of heavy ice, was closely cemented together by this year's frost ; it contained fewer icebergs than we observed last year.

We succeeded in reaching Allman Bay, half-way between Cape Hawks and Franklin Pierce Bay, but here the water ended, and the new ice was so strong that I thought it better to wait for the chance of an opening instead of forcing our way through it with full steam. On the following day, no sign of an opening occurring, and wishing to get to a more sheltered position on the western side of the bay, the Discovery being better adapted for the work than the Alert, led the way under full steam forcing a canal through the ice, which was I to 3 inches thick. She was several 
times completely stopped, until with all hands running from side to side on the upper deck and rolling the ship, she cieared herself and obtained headway again. At the head of Allman Bay we found a long valley leading down from the lofty hills far back in the interior filled with a gigantic glacier, probably extending eastward nearly to Iobbin Bay. It was named after Mr. Evans, the President of the Geological Society. In the Bay the temperature of the surface water was $32^{\circ}$, whereas since the frost had set in we had not met with any above 30 . On testing it was found to be nearly fresh, which fully accounted for the increased thickness of the newly formed ice. We afterwards found the same phenomenon in the neighbourhood of each glacier stream that we passed, proving that the water under the glaciers being cut off from the increasing cold remains unfrozen, and running after the temperature of the air is considerably below freezing" point.

The ice prevented our further movement until September 6 . Early on the 7 th, after one halt to allow the ice to open, we reached Norman Lockyer Island, with water channels for a third of the way across Princess Marie Bay. The season was now getting so late that one false step would probably entail our passing another winter in these seas without any adequate result being derived; therefore before attempting to cross the bay I walked to the summit of the island with Capt. Stephenson, and from there we had the cheering prospect of seeing a large space of open water some twenty miles distant from us which we knew would extend to the entrance of Smith's Sound, with only a few troublesome-looking nips between us and it. Making a signal to the ships we hurried on board, and with the exception of one nip which cost us an hour to clear away with all hands on the ice, and the Discovery charging at it repeatedly with full steam, we succeeded in getting two-thirds of the distance across the Bay ; but there we were stopped by three extensive Paleocrystic floes which tozzled in between some grounded bergs, and Cape Victoria prevented the ice from drifting out of Princess Marie Bay. The open water was now in sight from the mast-head, but the suppiy of coal was getting so low that if we did not succeed in releasing the ships the allowance for the second winter would have to be much reduced. On the gth, as the ice moved at the change of tides, we advanced about a mile. On the morning of the 1oth, observing that the heavy ice was likely to pass clear of the icebergs which imprisoned it, steam was got up ready, and five minutes after the channel was opened we passed through and found ourselves clear of Cape Victoria.

After this there was only one serious obstacle to our advance. Owing to the very calm weather the new ice had now frozen so strong that full steam was always necessary, particularly so wherever we had to force our way through ice where scattered pieces of old ice had been re-frozen closely together. At our last barrier of this kind, after the Alert had repeatedly charged the nip with full steam and considerable speed on, with no result, the Discovery ranged up alongside, and there being a narrow piece of heavy ice which would prevent the two ships actually touching, we made a charge together, and succeeded in forcing the batrier and gaining the open water beyond. From here the water channel permitted me to make a clear run for Cape Sabine, the ice opening as we advanced until none was in sight from the mast-head. On passing the entrance of Hayes Sound a considerable quantity of ice was observed some distance inside it.

In comparing the voyage of the Polaris and that of the Alert and Discovery, I believe that a vessel might have passed up the channel with equal fortune as the Polaris without encountering ice during the south-west gale we experienced in the middle of September, 1875. The heavy sea which on that occasion was produced in Robeson Channel indicated that there was a considerable stretch of clear water to the southward. The difficulty would be the choice of a starting point so late in the season after the frost has set in. If carefully navigated, a vessel, although kept ready to make a start, ought by that time to be secured in a sheltered position fit for wiriter quarters and, therefore, would most probably be unable to reach the channel of open water when it formed. If incautious, she would be as helpless in the pack. The best starting points are Port Foulke and Port Payer, at the entrance of Smith's Sound. The Polaris' quick passage north was entirely due to her leaving the entrance of Smith Sound at an opportune moment late in the season; had she left at any other time she would have experienced the same trouble in getting north in $187 \mathrm{r}$ as in returning south the following year. There was as much in the channel in $187 \mathrm{I}$ as in $1872-75-76$. To the latitude of Polaris or Discovery Bay, if no accident happens to the ship, the passage may probably be made with perseverance most years by start ing early in the season, but it will at all times be a most dangerous one.

In Robeson Channel the difficulties are greatly in creased, and the passage may be said to depend as much on a fortunate combination of circumstances as on skilful navigation. The present expedition was 25 days in going and returning between Cape Sabine and Discovery Bay, the distance being 250 miles ; 7 days in proceeding from Discovery Bay to the Arctic Sea, and 12 days in returning, the distance being 76 miles.

Sail was only used once on the passage north, the distance run being 20 miles, it was never used during the passage south. It is, therefore, totally out of the question a sailing vessel ever making the voyage; nevertheless, as full steam was only necessary on two occasions, a powerful steamer is not necessary. When the ice is decidedly closing no power at present available is of the slightest use ; when it is opening, easy speed generally carries the ship along as fast as the ice clears away in advance of her; it is rarely that a quick dash forward is necessary.

In a very exceptional season a ship might be carried nearer towards Cape Joseph Henry than Floeberg Beach on the west shore, and probably into Newman Bay on the east shore of the entrance to Robeson Channel; but from the experiences we have gained I most confidently report that no vessel will ever round the promontory of Cape Joseph Henry, or pass beyond Cape Brevoort in navigable water.

Every observation indicates that the last few years have been mild at the settlements on the west coast of Greenland, and open seasons with regard to the ice in Baffin's Bay ; little or none having been met with north of Cape York in July and August. The settlement at the Whale Fish Islands has been temporarily withdrawn, owing to the thin state of the ice rendering the fishing dangerous; and the temperature of the water as we proceeded south, through Baffin's Bay, was so high that navigation could scarcely be interrupted off Disco before the end of the year ; indeed, the Inspector intended to be absent in an open boat in the month of November. With a maximum body of water the ice formed on it in one winter will be considerably lighter or thinner than it would be, had a quantity of ice been left floating about on its surface ready to be re-frozen thicker, and cemented with the new ice into one floe during the coming winter. Thus, one open season certainly leads to another; and unless fortuitous circumstances occur, such as continuous south-west gales, during the summer months, the season of 1877 must be a very open one in Baffin's Bay. North of Smith's Sound the season is probably entirely different to that of Baffin's Bay, for the same northerly winds that carry the ice to the southward towards Davis Straits, must fill up Smith's Sound with heavy Polar ice and produce a cold season. Southerly winds which keep the ice north in the Bay would as certainly clear out the channels to the northward, empty the ice into the Polar Sea, and produce a milder season than usual. 
From Hayes Sound to Cape Beechey, in lat. $81^{\circ} 52^{\prime} \mathrm{N}$., where Robeson Channel is only thirteen miles across, numerous Esquimaux remains stud the whole line of the west shore of Smith's Sound. To the southward of Cape Beechy the coast ine affords fair travelling, to the northward the precipitous cliffs cut off all further advance, except during the depth of winter, when the ice in the channel is stationary. A very careful examination was made of the coast north of Cape Union, and I can report with confidence that Esquimaux have never had a permanent settlement on that shore. All the facts collected by our numerous observers lead me to conclude that the wanderers crossed Robeson Channel from Cape Beechey to Cape Lupton, where the Polaris Expedition discovered their traces.

The few pieces of drift wood, all of the fir or pine species, that have been obtained on the shores of the Polar Sea have evidently drified to the position in which they were found from the westward. Orie piece was obtained lying on the surface of the sea ice itself, two miles distant from the land, the rest were found on the shore at different beights above the sea level up to I 50 feet; the former was perfectly fresh with the bark on; the latter in all stages of decay, usually imbedded in the mud of dry ancient lakes evidently formed by the rising of the land, and of very great age. Besides these evidences of the rising of the land, the clearly defined smoothing of the rocks at all the prominent capes, from the present ice level up to 3 co and 400 feet until the marks are lost in the gradually decomposing rocks, caused by the pressure of the bordering ice-foot and the grounding ice as it is forced against the land by the drifting pack, and the numerous sea-shell beds and mud deposits at high elevations were most noticeable.

At Flocberg Beach the salt-water ice formed during the vinter attained its maximum thickness of $75 \frac{1}{2}$ inches early in June. In a fresh-water lake at the same date the ice was $79 \frac{1}{2}$ inches thick, with 12 feet depth of water at a temperature of $32^{\circ}$ below it. This proves decidedly that the deep lakes do not freeze to the bottom during the winter. The lowest temperature registered by a thermoneter buried 2 feet in the ground beyond the influence of any sudden variation was 13 degrees below zero; 59 degrees warmer than the air at the time. It rose gradually as the summer advanced, and at the end of July had risen to $295^{\circ}$. By that time the ravines had nearly stopped running, and the weather was becoming gradually colder. The sun's rays were most powerful on June 13 and $2 \mathrm{I}$, when a thermometer, with a blackened bulb in vacuo, registered +128 and +129 degrees, the temperature of the earth's surface at the time being +27 and of the air +34 degrees.

The coldest temperature of the sea-water during the winter was $28.25^{\circ}$, the same at all depths. On several occasions the Casella reversible thermometer showed that the temperature of the surface water, south of Robeson Channel, was colder than that of the underlying stratum, the difference amounting on one occasion to $1 \frac{1}{2}$ degrees Fahrenheit.

At Floeberg Beach the time of high water full and change, roh. $44 \mathrm{~m}$.; spring rise, $3 \mathrm{fr}$. oin.; neap rise, Ift. 7 int. ; neap range, oft. 5 in.

As I had deposited a notice of our proceedings at Norman Lockyer Island and intended calling at Cape Isabella I ran past our station near Cape Sabine without visiting it ; observing that the cairn was intact and appeared to be in the same state as we left it. Payer Harbour and the neighbourhood was clear of ice.

We arrived off Cape Isabella on September 9, the weather still remaining calm. On landing, a small mail of letters and newspapers which had been left by the Pandora was found at the depôt, the dates informing us that the visit was made this year, but beyond a notice stating that if possible a duplicate box of newspapers would be landed at Cape Sabine, we found no record ot her previous or intended movements. Concluding that the remainder of our mail was left at Disco, and being short of coal, and the weather very calm. I pushed on towards the Carey Islands, without losing time by visiting Littleton Island on the opposite side of the strait. A southerly wind springing up, the ships were put under sail. Beating to the southward, we fetched into Whale Sound on the IIth without meeting any ice since leaving Smith's Sound. The wind having freshened into a gale I anchored in Bardin Bay on the evening of the 12 th, where we observed some Esquimaux on shore, but the weather continuing very bad, I, unfortunately for them, put off communicating until the following day. On the same night the wind shifted suddenly and forced us to get under weigh, when the misty weather and a dark night prevented my landing at their settlement. The rock $a$-wash off Cape Powlet, the east point of the entrance on which the Esquimaux village stands, is very dangerous. There is no good anchorage obtainable outside of Tyndall Glacier; we were obliged to anchor in twenty-three fathoms in a position exposed to the northward, the Discovery making fast astern of the Alert.

During the I 3 th and I 4 th we worked to the southward towards Wolstenholm Island with calm and light airs from the west, which prevented my reaching the Carey Islands except at a large expenditure of our rapidly diminishing stock of coal; the heavy swell left from the late southerly gale would also have prevented our landing; accordingly our letters, left there the previous year by the Pandora, were obliged to be sacrificed.

From Wolstenholm Sound a south-easterly wind enabled us to fetch across to Cape Byam Martin at the entrance of Lancaster Sound, where we arrived on the 16 th, having seen no field ice, and the temperature of the sea-water ranging from 31 to 34 degrees. Steaming to the eastward on the 18 th, we met another south-east wind, which carried us into the south part of Melville Bay, and we proceeded south along the Greenland shore. I preferred recrossing Baffin's Bay rather than by standing to the southward risk getting in-shore of the middle ice on the west side. On the zoth Cape Shackleton was sighted, and on the $25^{\text {th }}$ we arrived at Disco, having had persistent head winds since we left the entrance of Smith's Sound on the roth. Only one light stream of ice was fallen in with all this part of the voyage. Here $\mathrm{Mr}$. Krarup Smith, In -pector of North Grecnland, most considerately allowed us to take 30 tons of coal out of his small store, and informed me that there were 20 tons more at my disposal if I would visit Egedesminde; and in order to give the Expedition the full benefit of his presence in obtaining supplies, Mr. Krarup Smith accompanied the ship to that port. Nothing could exceed his kindness to us during our stay. Finding that several of the inhabitants of Egedesminde were attacked with scurvy, I made the Governor a present of lime-juice for general use. From Mr. Smith we learnt that all our letters, with the exception of the few left at Cape Isabella, had been deposited at Littleton Island. Only a few letters were received at Cape Isabella, therefore a large mail of private and official correspondence has been lost.

After coaling and preparing the ships for sea we left Egedesminde on October 2. On October 4 the two ships recrossed the Arctic Circle, exactly fifteen months from the time of crossing it on the outward voyage. Experiencing contrary winds, slow progress was made to the southward. As the weather became warmer and damper a few mon were attacked with rheumatism and colds. On the 12th, during a very severe gale, in which the ships were hove to under a close-reefed main topsail and storm staysail, the Alert's rudder head, sprung when the ship was in the ice, worked adrift from the irons with which it had been repaired, the lower part of the rudder being sound. As I had neglected to have the rudder 
pendants shackled on before leaving port, it was with no little difficulty that make-shift rudder pendants were improvised; but by their means the ship has been steered across the Atlantic, the sails being trimmed to bring as little strain as possible on the rudder. The Discovery was lost sight of during a heavy gale on the igth. During the passage, southerly winds prevailed. The spare rudder, itself badly sprung, has been repaired, and is in serviceable condition; when it is shifted the Alert will be ready to proceed to Portsmouth. Captain Stephenson, before parting company, was ordered to rendezvous at Queenstown.

In conclusion, it is my pleasing duty to inform you for the information of their Lordships, that one and all under my command have done their duty well and nobly, the utmost cordiality prevailing throughout the members of the Expedition from first to last. Capt. Stephenson has been a most valuable colleague, and I am much indebted to him for his friendly advice, and ready help on all occasions.

The executive officers have each been mentioned in the detailed reports of Capt. Stephenson and myself; their conduct when taxed to the utmost, under difficult and most distressing circumstances, is beyond all praise. Much as the attack of scurvy which visited us is to be regretted, it proved how valuable were the services of Flect-Surgeon Thomas Colan, M.D., and Staff-Surgeon Belgrave Ninnis, M.D., who were so ably assisted by Surgeons Edward Lawton Moss, M.D., and Richard William Coppinger, M.D. These officers are each of great talent and high character, and have fully borne out the confidence imposed in them by the Medical DirectorGeneral; any reward that it is in the fower of their Lordships to bestow on these gentlemen could not be given to more careful or zealous officers.

Lieuts. Lewis Anthony Beaumont and William Henry May, who voluntarily undertook the navigating duties in their respective ships, have performed that work most ably.

Lieuts. May and Robert Hugh Archer have charted the coast line from the entrance of Smith's Sound to the northward with great exactness; these officers have earned their Lordships' commendation.

The Expedition is much indebted to Mr. Thomas Mitch ell, Assistant Paymaster-in-charge ; the departure of the Assistant Paymaster of the Alert has much increased his work, as the only officer of his rank in the Expedition. In order the more readily to assist me, he performed a sledge journey in the early season from the Discovery to the Alert, and has since then divided his time between the two ships. He is a steady and trustworthy officer, and as such I recommend him for promotion. Mr. Mitchell and Mr. George White, Engineer, have made a most valuable collection of photographs of subjects connected with Arctic life and scenes.

The Engineers of the two ships have always most zealously assisted, like everyone else, in the general work, and fully occupied their spare time for the benefit of the Expedition.

Messrs. James Wootton and Daniel Cartmel deserve great praise for the invariable excellent order in which the engines under their charge have been kept, and for the careful economy of the coal supply, a vital point in Arctic exploration. Messrs. George White and Matthew Richard Miller are each careful and talented officers. I most confidently recommend the claims of these four gentlemen, who were voluntarily employed with the support sledges, to the favourable consideration of their Lordships.

The two ships' companies have conducted themselves in the most praiseworthy manner throughout; they are specially commendable for their resolute perseverance during the trying sledge journeys which have been already reported. Their good conduct and zeal entitles them to the most favourable consideration of their Lordships. A list of men specially deserving of and fit for advancement to higher rates will shortly be forwarded.

\section{OUR ASTRONOMICAL COLUMN}

The November Meteors. - The earth will arrive at the descending node of the first comet of 1866 (Tempel), in the track of which the meteors of the November period are found to travel, early on the evening of the $13^{\text {th }}$ inst. The comet itself is approaching the point of nearest approximation to the orbit of Uranus, which planet, however, is always far removed from the comet during the present revolution. The distance from the earth on November 13 is $19^{\circ} 06$, and from the sun 18.11 , the mean distance of the earth from the sun being taken as unity; and were we able to reach the comet with our telescopes it would then be found rather more than one degree to the west of $\mathrm{An}$ tares. The obvious existence of more than one point of excessive condensation in this stream of meteors, necessitates a strict watch at each return of the earth to the nodal point, if we are to arrive at a clear knowledge of the law of distribution along the orbit, and as was remarked by M. Leverrier, "cela permettra de comprendre ces questions dans une théorie plus précise."

Herschel's First Glimpse of Uranus. - IIerschel's first observation for position of this planet on the night of discovery, March 13, 178r, was made at roh. 30m. M.T. at Bath, when he found it $2^{\prime} 48^{\prime \prime}$ distant from a star which he calls $\alpha$. For those who are curious in such matters it may be stated that the tabular place of Uranus at this time is in right ascension $5 \mathrm{~h} .35^{\mathrm{m}} .4^{8} \cdot 2 \mathrm{~s}$, and north polar distance $66^{\circ} 27^{\prime} 3^{\prime \prime}$, whence it appears that Herschel's first comparison was made with the star Argelander Z. $+24^{\circ}$, No. ro67, estimated $9.5 \mathrm{~m}$.; the difference of one minute of arc, between the observed distance and that computed on reducing the star to March, $178 \mathrm{r}$, being probably due to error of position in the "Durclimusterung." The log-distance of Uranus from the earth was $\times \cdot 2774$.

Tine Transit of Venus, I882.-Prof. Bruhns has circalated the results of a new calculation of the circumstances of this transit, made from Leverrier's tables of sun and planet, on the method adopted by Hansen for the transit of 1874 . These results, allowing for small. differences in the semi-diameters employed, are quite in accordance with those previously published by Hind, Puisseux, \&c. Prof. Bruhns hopes to issue a chart of the limiting curves in this transit, founded upon this new computation, before the end of the present year.

Mr. Knobel's Catalogue of the Literature of SideREAL Astronomy. - One of those exceedingly useful, but monotonous and laborious performances which exhibit the real zeal of the worker, occupies a large portion of the supplementary number of the "Monthly Notices" of the Royal Astronomical Society. It consists of a list of references to books, papers, \&c., bearing upon the following subjects connected with stellar astro. nomy :- I. Double Stars, and the investigation of the orbits of Binary Systems ; 2. Variable Stars ; 3. Red Stars ; 4. Niebula and Clusters; 5. Proper Motions; 6. Parallaxes of Stars; 7. Stellar Spectra; and, in the formation of this list, Mr. E. B. Knobel has had the advantage of the valuable library of the Royal Society, which is known to be remarkably rich in scientific transactions, \&c., in addition to the library of the Royal Astronomical Society, to which numerous and important additions have been made of late years. In such a work it might not perhaps be difficult for any one who has interested himself in a particular branch of sidereal astronomy to suggest some addition which he would like to have seen incorporated. For instance, if a calculator of double-star orbits be looking up measures o $\alpha$ Centauri, he will find no reference to the valuable measures by Mr. I. B. Powell, at Madras, under his name. 